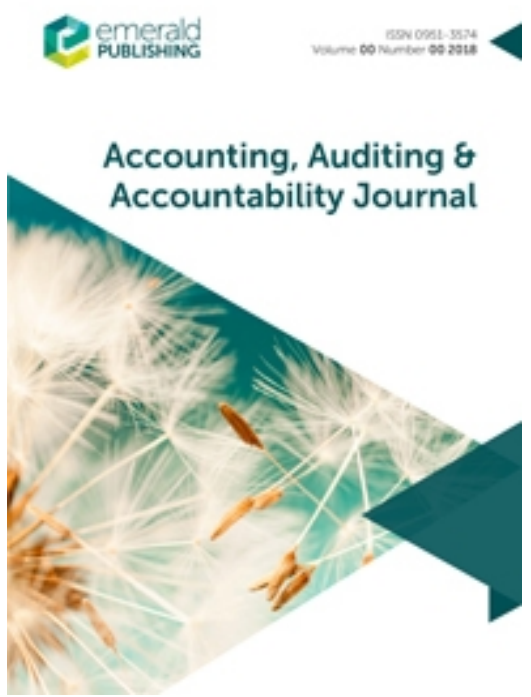

\title{
The Boundary of Sustainability Reporting: Evidence from the FTSE100
}

\begin{tabular}{|r|l|}
\hline Journal: & Accounting, Auditing \& Accountability Journal \\
\hline Manuscript ID & AAAJ-05-2018-3478.R2 \\
\hline Manuscript Type: & Research Paper \\
\hline Keywords: & $\begin{array}{l}\text { Boundary, Content Analysis, FTSE100, Sustainability Reporting, Global } \\
\text { reporting initiative, corporate social responsibility reporting }\end{array}$ \\
\hline Authors: Samantha Miles \& Kate Ringham \\
\hline
\end{tabular}

\section{SCHOLARONE \\ Manuscripts}




\section{The Boundary of Sustainability Reporting: Evidence from the FTSE100 Abstract}

\section{Purpose}

The aim of this paper is to use a multidisciplinary theoretical understanding of boundary setting to develop a quadripartite model in which sustainability reporting boundaries are classified as 'Reputation Management', 'Ownership and Control', 'Accountability; and, 'Stakeholder Engagement'. Content analysis is then used to empirically test the model.

\section{Design/approach}

Using impression management theory, rationalism, systems and contingency theory, and network theory a model is created which classifies sustainability reporting boundaries. Content analysis is used to empirically test boundaries across the disclosure of $49 \mathrm{GRI}$ topics by the FTSE100.

\section{Findings}

Sustainability reporting fails to discharge accountability due to adoption of narrow 'Reputation Management' boundaries. Boundaries are significantly $(p<0.0001)$ narrower than previous research suggests. Findings support Impression Management Theory as the strongest theory to predict reporting content. An Ownership and Control boundary, although widely criticised, represents the boundary of progressive reporters, lending marginal support for economic theories. Accountability boundaries are scarce. No evidence was found for Stakeholder Engagement boundaries.

\section{Practical Implications}

The determination of boundary is critical to the discharge of accountability. A critical consideration of boundary setting is required, including authentic stakeholder engagement in determining boundaries and transparency of boundary adopted. The results are ranked to enable benchmarking of the FTSE100. Boundaries can be widened through regulation or 'name and shame campaigns'.

\section{Originality/value}

This paper provides a theory-informed advancement in thinking on sustainability reporting boundary setting and the importance of this for advancing sustainability reporting quality.

Keywords: Boundary, FTSE100, GRI, Reputation Management, Rationalism, Sustainability Reporting. 


\section{Introduction}

Sustainability reporting has been criticised for being subject to managerial capture and failing to discharge accountability (Burritt and Schaltegger; 2010; Henri and Journeault, 2010; Joseph, 2012; Milne and Gray, 2013; Spence et al., 2010). It is unfit for purpose. Many critical thinking solutions have been advanced which call on academics and practitioners to learn from other disciplines (e.g. Rodrigue et al., 2013; Tregidga et al., 2014). This paper follows this multi-disciplinary approach with regards to a meta-level issue that has received limited academic attention: boundary setting.

The boundary marks the limits of an organization's accountability: what activities stakeholders may reasonably expect an organization to report on. Should an organization report on the sustainability performance of its joint ventures or outsourced activities, the end of use disposal of its products or the sustainability performance of its supply chain? Archel et al. (2008) and Antonini and Larrinaga (2017) found that, in practice, sustainability reporting boundaries fall short of providing comprehensive transparency over corporate impacts and that management fail to disclose how boundaries are set. Managers are able to manipulate reporting content through careful selection of boundaries to emphasise certain impacts over others, or to avoid reporting without justification. Transparency of impact is questionable if boundary setting processes are not communicated. The result can be a 'comprehensive' report that 'legitimately' omits the majority of the organization's impacts, because those impacts were deemed of no concern for accountability because they fall outside the reporting boundary. It is also possible to do this whilst claiming compliance with sustainability reporting guidance (Archel et al., 2008). This problem is exacerbated by the voluntary nature of sustainability reporting: boundary setting is devoid of regulation and has been subject to limited guidance (See GRI, 2005 as an exception).

Archel et al., (2008), Antonini and Larrinaga (2017) and Kaspersen and Johansen (2016) evidenced that sustainability reporting boundaries are strategically set and focused around the traditional financial reporting boundary associated with ownership, control and significant influence. This adoption of an ownership and control boundary is a largely unchallenged assumption (Lamberton, 2005) but has been subject to some criticism (Gray, 2006) for failing to fairly present sustainability impact (Kaspersen and Johansen, 2016) and falling short of the accountability expectations of users (GRI, 2005). Ringham and Miles (2018) evidenced that on average the global airline industry selected cherry-picked 'reputation management' sustainability reporting boundaries, indicating that adopting a financial reporting boundary would represent an advancement in practice. This is a serious problem as manipulated reputation management boundaries are duplicitous. To be accountable is to be answerable to others and to reduce the concept of accountability to the pursuit of one's own aims is to misconstrue accountability (Shearer, 2002) and shun responsibility. Decisions on the inclusion or exclusion of impacts such as pollution or resource consumption are political activities (Archel et al., 2008) which have moral consequences (Francis, 1990; Llewellyn, 1994), notwithstanding that it significantly reduces the usefulness of sustainability reports in assessing sustainability impact.

The aim of this paper is to use a multidisciplinary theoretical understanding of boundary setting to develop a quadripartite model in which sustainability reporting boundaries are classified as 'Reputation Management', 'Ownership and Control', 'Accountability; and, 'Stakeholder Engagement'. Content analysis is then used to empirically test the model. The empirical focus of this evaluation is the sustainability reporting boundary setting practice of the largest 100 companies listed on the London Stock Exchange (FTSE100). The GRI is used instrumentally to identify sustainability disclosure topics.

The findings contribute to the theoretical understanding of sustainability disclosure. The concept of boundaries is interdisciplinary and multifaceted (Heracleous, 2004). We have drawn on a range of interdisciplinary theories to provide insight into sustainability reporting 
boundary determination, including systems theory, contingency theory, economics theories based on rationalism (resource dependency theory, theory of property rights and transaction cost theory), the ideas of constructionism from anthropology and geopolitics, actor network theory from sociology, stakeholder theory from business ethics and the reputation and impression management literature from sociology and social psychology. Analysing motivations for boundary setting from multidisciplinary theoretical perspectives provides greater insight into, and understanding of current practice. This extends thinking on boundary setting within sustainability reporting which was previously based on an assessment of sustainability reporting guidance (Ringham and Miles, 2018), ecological/planetary boundaries (Antonini and Larrinaga, 2017) and organizational and operational boundaries (Archel et al., 2008).

This research contributes to the wider area of sustainability reporting research, which has historically concentrated around reporting content rather than boundary setting. Legitimacy theory, stakeholder theory, institutional theory and agency theory have previously been used to explain voluntary disclosure. The findings of the current research provide no support for stakeholder theory and limited support for agency theory. Findings partially support a legitimacy theory perspective but only to the extent that companies set boundaries as part of impression management, suggesting that further application of reputation and impression management theories are called for.

Boundary setting has attracted attention of sustainability guidance providers (e.g. CDSB, 2015, GRI, 2016) but has been largely ignored by academics. Six articles have focused on this area to date. Kaspersen (2013) and Egels-Zandén (2017) explored sustainability reporting boundary setting through interviews with 23 Danish and 12 Swedish corporations respectively, whereas Antonini and Larrinaga (2017), Archel et al. (2008), Pesci and Andrei (2011) and Ringham and Miles (2018) empirically tested boundary classifications using content analysis. The current research presents the most comprehensive evaluation of sustainable development boundaries to date for the following reasons:

i) A quadripartite boundary model for sustainability reporting is proposed. This provides a more nuanced and detailed understanding of boundary setting compared to the dichotomous classifications (organisational versus operational boundaries) applied by Antonini and Larrinaga (2017) and Archel et al. (2008). The quadripartite model provides theoretical support for the conceptualisation of the tripartite vision of boundary setting proposed by Ringham and Miles (2018), from their analysis of sustainability reporting guidance, and identifies a further, more progressive boundary classification based on stakeholder engagement;

ii) The empirical results are more generalizable than prior studies as the research explores: a wider range of companies compared to GRI compliant companies (Archel. et al., 2008; Antonini and Larrinaga, 2017) and the airline sector (Ringham and Miles, 2018); more than twice the range of stakeholder issues $(n=49)$ (Archel et al., 2008, $n=11$; Antonini and Larrinaga, 2017, $n=14$; Ringham and Miles, 2018, $n=22$ ) and; evaluates practice at a greater number of organizations ( $n=100$ ) (Ringham and Miles (2018) $n=35$; Archel. et al. (2008) $n=57$ and Antonini and Larrinaga (2017) n=92).

The paper is structured in the following way. Firstly a review of the multi-disciplinary literature on boundary constructs is presented. This is then ordered, filtered and applied to boundary setting within sustainability reporting culminating in the conceptualization of a model for sustainability reporting boundaries. Methods are detailed before the results, derived from statistical analysis of the sustainability disclosure of the FTSE100 companies across $49 \mathrm{GRI}$ topics, are discussed and conclusions drawn.

\section{Boundary Constructs}


Boundary constructs specify the limits of a field of enquiry. It is of interest across disciplines to demark cultural, political, social or religious borders, the margins for ecosystems or to define limits for responsibility or accountability. This section explores the main interdisciplinary theoretical perspectives that have been used to explain and predict the nature of boundary drawing for organizations and to discuss how these may apply to accounting and sustainability reporting.

\section{Rationalism}

Early contributions to classical organisation theory considered boundaries as metaphors for containment, defining organisations as clearly delineated units of economic activity operating within a legal, bureaucratic or administrative shell (e.g. Morgan, 1986). Boundary drawing was explained in relation to economic theories based on property rights, agency and transaction cost theories. Boundaries are drawn to minimise transaction costs and differentiate activities that are more efficiently internationalized from those that are better coordinated by the market-place. Infrequent transactions of standardised services/products requiring no specific asset investment are rationally outsourced, whereas frequent exchange of complex services/products involving specialised assets are best coordinated within the organizational boundary. The internalization/externalization decision is influenced by available capabilities and opportunism and the degree of risk and uncertainty evident, for example excluding suppliers of not-for-sale products, occasional suppliers or small scale supply from the organisational boundary (Engels-Zandén, 2017).

Financial reporting boundaries are based on rationalism, as provision of information is directed towards short-term economic decision-making of shareholders and creditors. The limits of the reporting organisation is intended to be a closed system to ensure the annual report captures the entire group of companies as if it were a single entity, albeit creative accounting schemes may render boundaries mutable in practice. This reflects the property rights perspective of boundary drawing: organisations where ownership, control or significant influence over assets is evident are included within the reporting boundary and investments lying outside of this legal definition are excluded. Financial reporting boundaries are determined by rules that are influenced by economic theories. For a transaction to be included within the reporting boundary it must be capable of being measured in monetary terms with reasonable certainty (thereby reducing uncertainty and risk) and must be material in nature. Materiality is assessed relative to economic reference (the impact on profit or turnover) and rationalism as it is determined by a market logic (based on financial impacts and a shareholder focus) and a professional logic (to enable efficient auditing) rather than a stakeholder (accountability) logic (Edgley et al., 2015).

Sustainability reporting should logically follow a wider boundary than one defined through theories of economic rationalism, although evidence suggests otherwise. Lamberton (2005) accused sustainability reporting guidance setters of adopting the nomenclature of financial reporting, and associated economic boundaries, without challenge, permitting companies to narrow accountability to those areas where control and ownership reside. This was evident in the first iteration of the GRI (2000) which suggested the financial reporting boundary should be used as a 'starting point' for sustainability disclosure. GRI (2000:13) proposed that "an organization may wish to expand its boundaries ... to capture upstream and downstream effects of its products and services" [emphasis added] to include the supply chain and a consideration of total life-cycle impact of products/services. Archel et al. (2008) argued that given the voluntary nature of reporting permitting an option that organizations 'may' wish to expand boundaries would result in organizations ignoring such advice.

The tenets of rationalism remain evident within current sustainability reporting guidance. As an illustration, the approach to boundary setting for CDSB (2013:12) is in accordance to "the type of control and influence exercised by a reporter over an entity, which may be (i) financial, (ii) operational and/or (iii) an equity share". This clearly embraces financial 
reporting terminology and advocates shareholder, rather than stakeholder primacy, and an associated narrow boundary setting. The reporting boundary for the integrated reporting framework included "risks, opportunities and outcomes attributable to or associated with other entities/stakeholders beyond the financial reporting entity that have a significant effect on the ability of the financial reporting entity to create value" (IIRC, 2013:19). Whilst appearing to promote a wider boundary there are two qualifiers here that act to the contrary as there is no definition of 'risks, opportunities and outcomes' or 'value'. Bavagnoli et al., (2014) argued that such ambiguity would lead to the risks, opportunities and outcomes being determined from a managerial, rather than societal perspective, to delimit accountability. Likewise Flower (2015) debated that the value created would be interpreted as 'value for investors' rather than 'value for society' to avoid the disclosure of long-term externalities. Fombrun et al. (2000) argued that sustainability reporting is used as a means to reduce adverse selection and opportunism, through reduction of information asymmetries associated with agency costs. Strategic boundary adjustments could be undertaken to gain enhanced reputation and competitive advantage to minimise cost through improved credit ratings or cheaper access to financial markets in line with rationalism. Similar logic was applied by Karasek and Bryant (2012) in relation to signalling theory and Friedman and Miles (2001) in relation to risk management.

\section{Systems Theory and Contingency Theory}

The traditional conceptualisation of firms as closed organizational systems, in which boundaries are impermeable to the surrounding environment, was questioned post-1950 due to the emergence of an age of increasing complexity. Organizational boundaries were reconceptualised as flexible, permeable membranes. Two theories were central in this reconceptualization: Systems Theory (Katz and Kahn, 1966; Thompson, 1967), an interdisciplinary theory that examines the complexity of interactions between society, nature and science, and; Contingency Theory (Galbraith, 1977), which evaluates the impact of emergent environmental factors on decision-making. For both dynamism is an important characteristic of boundary setting, as organizations are considered to exhibit the autopoietic characteristics of a living system reacting to influences from the environment. This reflects Thompson's (1967) idea of spatial boundaries which encompass a zone of interaction (of inputs and outputs) and Morgan's (1986) idea of open systems which act as an interface of exchange between the organization and its environment. This also has parallels to the law of interaction within community ecology theory (Thornton and Tuma, 1995) whereby technological advancements act as binding structures leading to shifts in boundary setting, alienating companies with heterogeneous technological approaches and bringing together those that share unified technology.

Examining conditions of increased complexity, Llewellyn (1994) called into question the effectiveness of 'archaic' accounting systems to maintain boundary thresholds. She predicted that increased external pressures would create demands for new forms of accounting enacted through a shift of boundary activity and changes to the boundary gatekeepers. Numerous examples of boundary shifts in accounting have emerged over time, confirming Llewellyn's predictions, such as the acceptance of incomplete transactions as sufficient evidence of recognition in fair value accounting (Walton, 2006) and boundary shifts in relation to voluntary reporting of intellectual capital (Gowthorpe, 2009). The revised conceptual framework (IASB, 2018) provides a further example through the narrowing of the primary audience group for financial reporting (investors and creditors), explicitly excluding groups specified by IASB (2010): employees, suppliers, trade creditors, customers, the government and their agencies and the public.

Within sustainability reporting guidance GRI (2011) introduced the idea of the operational boundary, demonstrating alignment with contingency theory thinking. This encompassed a corporate's "ability to influence entities upstream [supply chain] as well as entities downstream [distributors/consumers]" (GRI, 2011:12). For Antonini and Larrinaga 
(2017) this is necessary to align reporting boundaries with the boundaries of ecosystem sustainability as ecological interactions transcend the boundaries of ownership. A contingency theory informed sustainability boundary appears sensible considering that major environmental incidents, such as an oil spill or chemical leak, may impact subsequent boundary decisions, not only for the company that is culpable, but for fellow industry members (through association) (Deegan, 2002).

The GRI's boundary protocol (GRI, 2005) recommended three reporting approaches depending on the level of control/influence identified: i) disclosure of operational indicators for entities over which control is exercised; ii) management indicators for instances of significant influence, and; iii) narrative disclosure for significant impacts from other entities. This reflects a permeable reporting boundary operating with a sphere of influence at its periphery. UNGC (2009) has adopted a similar approach. Envisioned as a series of concentric circles radiating outwards from the organization, high levels of control (i.e. direct impacts from core business activities) are differentiated from weaker control exhibited over the supply chain and, low levels of influence over community, social and philanthropic activities. The idea is that the wider the sphere of influence, the lower the expectation of disclosure. This reflects strategic stakeholder theory whereby only the most powerful stakeholders are likely to have influence at the boundary margins because they are crucial for organisational survival (Friedman and Miles, 2006). All other stakeholders remain conceptualised as occupying the space between business and society

\section{Network Theory}

The contingency theory approach to establishing boundaries is open to criticism for depicting boundary spanning as unidirectional: the environment influences the organization but impact of the organization on the environment is ignored. MacDonald (2011) called for a more heterogeneous reality, characterised by overlapping and complex webs of relationships, to replace the overly simplified spheres of influence model. Viewing boundaries as networks (Powell, 1990) directly addressed this issue. Boundaries are dynamic and amorphous, subject to constant (re)construction in response to multi-dimensional flows and interdependencies existing in the environment (Hernes, 2004). Networks are defined by needs for affiliation, acceptance, goal congruence and involvement, with members exhibiting these characteristics included within the network boundary and those not exhibiting these characteristics excluded. For example, Dyer and Nobeoka (2000) illustrated the widening of Toyota's organizational boundaries to encompass supply chain members due to its integrated sociotechnical production system. Resource dependency theory also uses the network metaphor to explain how boundaries have shifted in response to interdependencies associated with flexible specialization, commodity chains or knowledge-based networks (Thornton and Tuma, 1995). Change can be continuous leading to the appearance of a 'boundaryless' organization (Ashkenas et al., 1995). An alternative related perspective was presented by Hernes (2004) in which multiple sets of co-existing composite boundaries are sustained, each with varying strength and substance.

Actor network theory has been used to evaluate the role that accounting plays in construction of boundaries (e.g. Chua and Mahama, 2007). Llewellyn (1994) advocated that management accounting boundaries act as binding structures that promote common purpose, absorb social tensions and bind divergent goals through specification of input variables for decision-making techniques, as these variables become the focus of management attention. This symbolic perspective defines a boundary as 'demarcation of a difference in perspective, culture and identity' (Thrane and Sundtoft Hald, 2006:293) and represents the ability of a firm to mobilize and impact network members. This draws on ideas from sociology and anthropology in an attempt to connect boundary setting to the culture and value of organisational members. 
Examples of network theory informed boundaries exist within sustainability reporting guidance. AA1000 (2018), based on the principle of inclusivity, advocates that an organization include stakeholders in the determination of the boundary for reporting, and in its discharge of accountability, whereas GRI (2005) recommended stakeholder engagement in the creation of a stakeholder materiality matrix. This conceptualises stakeholders as occupying a space within the organizational boundary and draws parallels with normative stakeholder thinking and the notion of reciprocity (Phillips, 1997). AA1000 (2018) explicitly adopted a stakeholder logic to materiality (Edgley et al., 2015) whereby materiality should encompass wider social understanding and a more forward-looking perspective in determination of significant sustainability impacts on stakeholders.

\section{Social Constructionism}

Boundaries have frequently been conceptualised as socio-culturally constructed (Luhmann, 1995), being actively (re)produced as a consequence of dynamic and contested social/political processes. This perspective draws on literature from anthropology, culture studies, sociology, human geography and geopolitics. Boundaries (between nations, cultures, religions, class, gender, language, organisations etc.) are viewed as instruments for social distinction generated by social processes (discourse, knowledge, education, politics etc.) that differentiates and delimits 'self' from 'non-self', membership from nonmembership. Boundaries may be internally constructed, self-constructed between parties wishing to unite (reciprocal bounding) or imposed by external forces (ascriptive bounding), and may hold positive (a sense of belonging, solidarity and security) or negative (alienation and exclusion) connotations (Ryen and Silverman, 2000). Boundaries may exist on various spatial levels: a State may have rigid immigration boundaries, but fluid cultural identity boundaries influenced by traditions and experiences. Socially constructed boundaries are achieved through individual action (Llewellyn, 1994; Gowthorpe, 2009) and may be constructed on the basis of knowledge, ownership, internal contracts, external obligations (Grandori, 2000) or the psychology of members (Llewellyn, 1994). Socially constructed organisational boundaries may be enduring when based on embedded culture, or ephemeral if in response to an incident or urgent stakeholder claim. Viewing boundaries as social constructions has implications for where managers focus attention, how they act, and how others experience these actions.

Llewellyn (1994:11) argued that accounting information influences boundary drawing as it 'absorbs uncertainty, shapes expectations and makes some organizational activities more visible than others', for example, a capital expenditure model may incorporate financial costs and benefits but ignore stakeholder impact. Hines (1988) provided an early examination of the extent to which accountants and standard setters define financial reporting boundaries by specifying what gets recognised, measured and reported. In acknowledging the power that accountants have in changing the boundary construct, she captured the notion of a permeable, flexible and dynamic boundary. Lowe (2001) echoed Hines' (1988) ideas, viewing accounting as a productive force that constructs social relations. Likewise, drawing on corporate identity literature, sociology and anthropology Thrane and Sundtoft Hald (2006) connected management accounting boundaries to the culture and value of organisational members, acknowledging the active force of accounting in symbolic construction of boundaries ('accounting as actant').

Social constructionism is used within sustainability reporting literature to provide explanations for managerial behaviour in the determination of reporting content. This is evident in relation to boundary drawing through (mis)appropriation of concepts and language from financial reporting (Archel et al., 2008; Antonini and Larrinaga, 2017; Ringham and Miles, 2018) such as the interpretation of materiality using a market logic which advocates shareholder primacy (Edgley et al., 2015). This acts to reinforce rationalism through a narrowing of reporting boundaries. Further examples were provided by Banerjee (2003) and Milne et al. (2006) with respect to realignment of the definition of sustainability to match self- 
generated objectives for reporting, thereby validating corporate engagement with the sustainability agenda whilst reinforcing 'business-as-usual'.

Using impression management theories from sociology and social psychology Hooghiemstra (2000) demonstrated how sustainability reporting is used strategically as a public relations vehicle to influence external stakeholder perceptions. Impression management strategies may be acclaiming, whereby reporting is used to claim credit for desirable events where responsibility lines are ambiguous, or negative, based around the construction of excuses and justifications. This may be undertaken as a self-preservation device to demonstrate congruence of corporation actions with societal norms (Deegan, 2002) or as part of risk management to reduce agency costs (Fombrun et al., 2000). For example Bebbington et al. (2008) evidenced the use of cherry-picked content to reduce reputational risks from subsidiaries having poor sustainability performance and to enhance reputation management by best case examples. Ringham and Miles (2018) found support for a reputation management boundary within sustainability reporting, being much narrower than those advocated for financial reporting, as many activities that are owned, controlled or significantly influenced were omitted from the reporting boundary.

\section{A Conceptual Model of Boundary Setting within Sustainability Reporting}

Boundary setting within sustainability reporting has largely been overlooked by the academic community, despite being a central issue for accountability. Previous research has conceptualised reporting boundaries as dichotomous, differentiating between organizational boundaries (control and significant influence) and operational boundaries (upstream and downstream impacts of the supply chain, outsourced activities and life cycle assessments) (Antonini and Larrinaga, 2017; Archel et al., 2008; Kaspersen, 2013). Ringham and Miles (2018) proposed a tripartite approach to sustainability reporting boundary setting based on reputation management, ownership and control and accountability. Derived their model from a conceptual analysis of 40 boundary attributes evident within 15 sets of accountability standards. This paper takes a different approach: analysing the multi-disciplinary theoretical literature on boundary setting to extract boundary characteristics. This has provided theoretical support for the tripartite model proposed by Ringham and Miles (2018):

1. Reputation Management Boundaries are associated with the theories of impression management, signalling, legitimacy theory, agency theory and risk management. These perspective would suggest that the boundary is open. It is constructed defensively by management in response to risk management such as a recovery of external legitimacy evidenced by historic misdemeanours, or a reduction of information asymmetries to reduce agency costs of adverse selection and opportunism. The boundary is socially constructed as management cherry-pick which topics warrant an extended boundary setting and so this represents a partial organizational boundary. Good news in relation to selected topics will be brought inside the reporting boundary, and bad news excluded, unless deemed to support legitimation. Materiality is based on a market logic, with a focus on shareholder primacy. The provision of information to stakeholders is a means to an end (legitimation of actions) rather than for accountability.

2. Ownership and Control Boundaries are supported by economic theories of rationalism, particularly the theory of property rights and transaction cost theory. The boundary is closed. The boundary is socially constructed in so far as accountants determine the rules for consolidation, recognition and measurement. It reflects the organizational boundary. Management have discretion over boundary setting in so far as they make investment decisions and thereby determine what subsidiaries they wish to fully own or control, what operations receive partial investments (associates and investments) and what operations are outsourced. As rational decision-makers they are guided by economic efficiencies and the reduction of contractual hazards: transactions involving 
uncertainty, asset specificity and inter-firm interdependencies are internalized into the organizational boundary. Boundaries are socially constructed through 'voluntary' ascriptive bounding from financial reporting, and influenced by changes to accounting or legal reporting frameworks. Materiality is based on a market logic, with a focus on shareholder primacy. Provision of sustainability information to stakeholders is a byproduct of satisfying shareholder and creditor needs rather than for accountability.

3. Accountability Boundaries are explained by contingency and systems theories, strategic stakeholder theory, resource dependency theory and community ecology theory. The boundary is permeable. It is socially constructed in a tactical and accommodative manner as part of strategic stakeholder management. Boundaries are changeable within the zone of influence as management respond to salient stakeholder issues that become more or less material over time. The creation of binding structures within the zone of influence lead to shifts in boundary setting, for example, increased resource dependency on salient stakeholders will lead to a widening of the boundary to include those stakeholders within the organizational boundary. It represents the organizational boundary together with a partial operational boundary that internalizes some upstream and downstream concerns of salient stakeholders. Materiality is predominantly based on a market logic, as the boundary is managerially determined, but is adjusted to incorporate a stakeholder logic for urgent issues raised by powerful stakeholders operating within the zone of influence.

An evaluation of the multi-disciplinary theoretical literature has identified a fourth boundary setting explained by sociology, network theory and ideas of reciprocity associated with normative stakeholder theory:

4. Stakeholder Engagement Boundaries represent the widest reporting boundary. The boundary is dynamic, amorphous, composite and, at times ephemeral. It is socially constructed proactively, and jointly, by management and stakeholders (reciprocal bounding). The organization, as a nexus of stakeholders, is 'boundaryless': stakeholders are subsumed within the organizational boundary as they are recognised as part of the organizational network. The boundary represents the organizational and operational boundary to include indirect impacts from, and on, stakeholders Stakeholder engagement is used to determine material issues and reporting content. Materiality is based on a stakeholder logic as the symbolic perspective on shared values is constructed from an acknowledgment of accountability and transparency to all stakeholders.

Table 1 summarises the key findings from the multi-disciplinary literature and aligns key tenets with the four boundary categories identified. The only 'theoretical' approach that transcends all boundary concepts is constructionism. Boundary setting is a social endeavour, albeit the dominant force and philosophy driving the nature of the social construction differs between boundary categories: reputation management boundaries are socially constructed by management in response to perception management, representing managerial capture of reporting; ownership and control boundaries are socially constructed in an ascriptive bounding manner through the appropriation of terminology and concepts from financial reporting; accountability boundaries are socially constructed by management in response to stakeholder demands at the fringes of the boundary, and; stakeholder engagement boundaries are socially constructed in a reciprocal bounding manner, interdependently by stakeholders and management.

[Insert table 1 here] 
A conceptual model of sustainability reporting boundary setting is presented (Figure 1) depicting narrow to wide conceptualisations. The nature of the boundaries (hard or permeable) is depicted by the format of the line. Where permeable boundaries are influenced by stakeholder pressure the direction is indicated by the arrows, as unidirectional, or multidirectional. Stakeholder influences may vary according to stakeholder legitimacy, power and urgency of stakeholder claims (Mitchell et al., 1997) and this is denoted by the size of the directional arrows.

[Insert figure 1 here]

In order to operationalise this model hypothetical radar graphs were constructed under each categorization of boundary setting (Figure 2) according to GRI reporting content for a selection of GRI topics that are capable of being applied across all four boundary constructs. Two scenarios are presented: universal disclosure and unilateral (topic-by-topic) application, the latter being advocated by GRI $(2013 ; 2016)$.

[Insert figure 2 here]

\section{Method}

To evaluate the quadripartite sustainability reporting boundary model a content analysis of the published sustainability reports of the FTSE100 was undertaken.

\section{Sample}

Companies listed on the FTSE100 on July 2016 were identified. The FTSE100 was selected because the UK has historically been judged to be a leading nation in terms of uptake in sustainability reporting, particularly regarding large companies (KPMG, 2017). Relevant sustainability disclosure for 2016-2017 was identified and downloaded for analysis. Some companies produced multiple reports resulting in 136 reports for analysis. For eleven companies not producing a stand-alone sustainability report, relevant web-based reporting was interrogated.

\section{Content Analysis}

Content analysis is a tried and tested approach to analyse sustainability reporting content (Milne and Alder, 1999) and has been used for boundary analysis (Antonini and Larrinaga, 2017; Archel et al., 2008; Ringham and Miles, 2018). Sustainability reporting research has tended to use NVivo software or manual word searches to code absence (0) or presence (1) of sustainability disclosure issues, or the assessment of the quality of reporting (e.g. whether targets are set, bad news reported or audit undertaken etc.). This necessitates creation of a coding framework to demonstrate how consistency is maintained in the coding of key words against themes. This is not the approach adopted in this research which systematically adhered to the following set of rules for coding, measuring and recording data:

1. A coding rule was established to score reporting content of sustainability reports according to the four boundary constructs proposed:

If no disclosure on a topic (0)

If the topic disclosure boundary reflects:

- Reputation management (1)

- Ownership and control (2)

- Accountability (3) 


\section{- Stakeholder engagement (4)}

If the topic is not applicable to the sector $=$ (average score for topic).

2. The GRI was chosen as the framework from which reporting content could be systematically assessed, in line with Antonini and Larrinaga (2017), Archel et al., (2008) and Ringham and Miles (2018). The GRI is internationally recognised as a global leader in sustainability reporting guidance. Over $75 \%$ of the world's largest 250 companies report under GRI guidance and $63 \%$ of the largest companies in Europe. The GRI has been subjected to criticism (e.g. Milne et al., 2009), however this paper does not assess the validity of the GRI as a reporting framework as it is used instrumentally, as a way of identifying specific disclosures likely to be found in sustainability reports (Antonini and Larrinaga, 2017). The timing of the research coincided with the transition between the G4 Guidelines (GRI, 2013) and GRI Standards (2016) which are operational from 2018. Consequently both versions were reviewed. Two G4 topics have been discontinued in the current standard (EN27 and EN30) but were put forward for analysis given that members of the FTSE100 reported on them.

3. Reporting content was coded on a topic-by-topic basis rather than assuming an organization-wide uniform boundary construct, as 'topic boundaries vary based on the topics reported' (GRI, 2016: Glossary 17). Only the $91 \mathrm{GRI}$ standard disclosure topics relating to sustainability impact were included for consideration (i.e. the management approach disclosures were excluded (e.g. GRI 102-103 (GRI, 2016); G4-1-G4-58 and G4-DMA-a to c (GRI 2013)).

4. The following criteria rule for analysis was established:

As an example, disclosure across all four boundary constructs was deemed possible for EN1 (301-1) 'Material used by weight or volume': Boundary 1 (reputation management) via cherrypicking by site, region or material type; Boundary 2 (Ownership and control) via group consumption of materials; Boundary 3 (Accountability) via selected upstream use of materials e.g. from particular suppliers or for a particular product line, and; Boundary 4 (Stakeholder engagement) via comprehensive reporting of upstream use of all materials. Disagreements (for 13 topics) were discussed until agreement was reached. For example it was debated that 302-5(EN7) 'Reduction in energy requirements of products and services' could theoretically include energy management across the supply chain (Boundary 3 ) and energy use by consumers (e.g. a washing detergent manufacturer reporting saved $\mathrm{Co} 2$ emissions by consumers as a consequence of washing clothes at lower temperature) (boundary 4), and was therefore included for analysis. This iterative process led to removal of 43 topics that were incapable of capturing all boundary constructs, such as 302-1(EN3) 'energy consumption within the organisation' which by definition cannot exceed Boundary 2. This led to 49 topics for review (Appendix 1), categorised via topics relating to: Economic (ECON); Environment (ENVIRN); Human rights (RIGHTS); Labour practices (LABOUR); Society (SOCIETY), and; Product Responsibility (PRODUCT).

5. Agreement was made to collect the following information from the FTSE100:

i) Excerpts from the sustainability disclosure to illustrate different boundary settings for the same variable across companies and industries;

ii) Published boundary definitions to be recorded verbatim, classified as implicit or explicit and categorised according to boundary setting (1-4).

6. A spreadsheet was created detailing the corporate's name in the first column and the 49 selected topics across the top row. Coding was undertaken manually through a careful reading of the identified disclosure on a topic-by-topic basis for all 49 topics. A judgement was made on the maximum boundary setting evident. Krippendorff's alpha, a measure of inter 
coder reliability, was not calculated because coding was undertaken iteratively and reflectively by the two named researchers who, having developed the model and associated coding scale, were clearly informed as to what they were looking for and how to code disclosure. Confidence in inter-coder reliability was increased in the following way: i) two random reports were independently coded and the results compared and deliberated; ii) all ambiguous examples of boundary identification were highlighted for discussion prior to finalisation of coding, and iii) throughout the process random inter-coder checks were performed with discrepancies highlighted, discussed and subsequently resolved. Few discrepancies were identified, being less than $1 \%$ of all coded data, most of which related to whether a topic should be recorded as non-disclosure or not applicable for a particular industry.

7. On completion of coding the average disclosure per topic was calculated and assigned to all instances of non-applicability for that specific topic. This enabled the differentiation between instances of non-disclosure of material items for the sector (0) from non-disclosure of immaterial items (average score).

8. To facilitate comparison of results with previous research individual topic disclosure scores were divided by 4 (the number of boundary settings) to reflect a 0-1 scale. The disclosure scores should be interpreted as follows:

0-0.24 = reputation management boundary

0.25-0.49 = ownership and control boundary

0.50-0.74 = accountability boundary

$0.75-1.00$ = stakeholder engagement boundary.

For statistical regression analysis a comparison against a hypothetical mean was required. Given the nascent nature of this area the hypothetical norm is disputed. Consequently multiple regressions were undertaken based on the hypothetical mean identified from Archel et al. (2008) (0.4) and Ringham and Miles (2018) (0.3291). These required adjustments because Ringham and Miles (2018) and Archel et al. (2008) tested tripartite and dichotomous boundary classifications accordingly. Hence it would be inappropriate to compare the Ringham and Miles (2018) tripartite boundary mean of 0.3291 , which was classified as a reputation management boundary, with a quadripartite mean of 0.3291 which would be interpreted as indicative of an ownership and control boundary, as this would lead to incorrect interpretation of the results (see Table 2).

\section{[Insert Table 2 here]}

9. For comparisons of variables across categories (ECON, ENVIRN, LABOUR, RIGHTS, SOCIETY, PRODUCT) the cumulative score for each variables was divided by the maximum permitted score (i.e. the number of topics per category), as indicated in appendix 1. For example the number of topics varied from 3 (PRODUCT) to 25 (ENVIRN).

\section{Results}

\section{FTSE100 Boundary Definitions}

This paper represents the most comprehensive analysis of boundary to date given the wide range of topics $(n=49)$, sample size $(n=100)$ and analysis of boundary constructs $(0-4)$. This research sought to assess the nature, and frequency, of reported boundary definitions. A definition was provided by $74 \%$ of the FTSE 100 , albeit $53 \%$ of these providing implied definitions. Corporations were ranked according to the boundary disclosure index recorded 
over all $49 \mathrm{GRI}$ topics. All companies ranked in the top quadrant (1-25) provided either an explicit $(n=17)$ or implicit $(n=9)$ definition, whereas the majority of companies ranked in the bottom quadrant provided no definition $(n=16)$, with only 4 companies providing an explicit definition from this group. This indicates that the inclusion of a boundary definition is a rough proxy for a non-reputation management boundary setting.

A judgement was made as to whether the boundary definition was related to an organization-wide or topic boundary. The GRI requires corporations to report the boundary for each material topic but only $23 \%$ of the 39 FTSE100 claiming compliance to GRI standards adopted a topic boundary approach (British American Tobacco, BP, Carnival, Diageo, GSK, Hammerson, Mondi, Pearson and Unilever). Mondi provided a clear example of this. It defined its material impacts across the six GRI categories (ECON, ENVIRN etc.), stated which division within Mondi the impact was related and, provided an assessment of impact outside Mondi, such as indirect economic impacts on communities, indirect energy use in the supply chain or carbon emissions from transport. Centrica, Sainsbury and Next also adopted topic boundaries for some material impacts but without claiming GRI compliance. The majority of the 74 companies providing a definition opted for an organization-wide approach $(n=62)$, for example:

"Data is provided by all companies over which Associated British Foods has full operational control, does not fully own but has financial control, and joint ventures and associates where we do not have a majority shareholding but do have either joint control or significant influence" (Associated British Foods, 2016:2)

"We have chosen to use the operational control approach because we maintain the ability to direct the operating policies of each of our organisations, with a view to achieving economic benefits. Specifically excluded from the organisational boundary is our outsourced contact centre in Bangalore, India, which we do not have control over" (Admiral, 2016:19)

Of the remaining 15 companies providing a definition, 14 provided a narrower, selective boundary definition. Definitions were narrowed in a range of ways, for example, restricting an ownership and control boundary to environmental impact only (e.g. Sage) or specific examples of environmental impact (e.g. Intu Properties only defined a boundary for greenhouse gas (GHG) emissions), or by limiting the scope of accountability to selective stakeholders (e.g. WPP and Smiths Group).

Intercontinental Hotel Group (2016:7) was the only organization that disclosed an accountability-based organization-wide boundary:

"In developing our approach to responsible business, we consider all aspects of the hotel life cycle including our direct operations, our relationships with our owners and our supply chain".

This was misleading, given an overall disclosure score based on reputation management $(0.1746 \pm 0.2359)$, with only 2 topics reported under an accountability boundary (409-1 (HR6) and 302-5 (EN7)). This is duplicitous and supports previous findings of a "boundary gap" within sustainability reporting between the boundary definitions that companies disclose and the boundary adopted in practice (Ringham and Miles, 2018).

\section{Overview of Boundary Setting within the FTSE100}

The average boundary adopted by the FTSE100 across all topics was 0.2 (mean) \pm 0.22 (standard deviation), clearly indicating disclosure based on reputational management. This contradicts the boundary definitions published by the FTSE100 (see above), which were predominantly based on ownership and control (47/74 companies providing a boundary definition). 
A series of one-sample t-tests were run to determine whether the boundary score for the sample was different to 'normal'. The first series of t-tests adopted the hypothetical mean adopted by Archel et al. (2008). This was 0.4 , based on a dichotomous boundary classification, which equates to a 'quadripartite' mean of 0.2. Further tests were run using the variants for the aviation industry, provided by Ringham and Miles (2018) (adjusted hypothetical mean of 0.2468), plus specific adjusted disclosure indices for categories of GRI disclosure (0.14550.319). The results, together with descriptive statistics are detailed in table 3 . The disclosure scores were normally distributed (Shapiro-Wilk test) and there were no outliers.

\section{[Insert Table 3 here]}

The average boundary adopted by the FTSE 100 is lower than the average disclosure boundary reported by Ringham and Miles (2018) for the airline industry ( 0.2 compared with an adjusted mean of 0.2468). Significant results are observed across five categories (SOCIETY, RIGHTS, ENVIRN, ECON, PRODUCT) of GRI disclosure, indicating that sustainability reporting boundary specification within the FTSE100 is significantly $(p \leq 0.0001$ for $3 / 6$ categories) lower than the 0.2 adjusted hypothetical mean adopted by Archel et al. (2008). Boundary setting across the FTSE100 is also significantly lower $(p<0.0001$ for $3 / 6$ categories) than the average identified within the airline industry (Ringham and Miles, 2018), with significant $(p=<0.0001-0.0168)$ differences observed for five GRI categories when category specific adjusted hypothetical norms are adopted. This is surprising given that the airline industry is considered to lag other industries in sustainability reporting (KPMG, 2017).

The widest boundary construct was evident for ECON $(0.276 \pm 0.176)$, which marginally classifies as an ownership and control boundary. Given the monetary nature of data collection in this area this result is unsurprising, as organisations inclined to disclosure economic sustainability topics would capture relevant information as part of their financial reporting systems. The second widest boundary was observed for RIGHTS $(0.228 \pm 0.183)$. Boundary setting within this category has been greatly widened by the enactment of the UK Modern Slavery Act (2015) which required all companies with a turnover exceeding £36million to publish a statement outlining the steps taken to ensure prevention of slavery and human trafficking across operations, including the supply chain. Nevertheless the average boundary adopted across RIGHTS was still one of reputational management. The narrowest boundaries adopted related to SOCIETY $(0.133 \pm 0.143)$ and ENVIRN $(0.196 \pm 0.100)$ The result for SOCIETY is expected as societal impact beyond philanthropic donations and employee volunteering has traditionally been linked to reputation management (Bebbington et al., 2008). The result for ENVIRN is unexpected given: i) the longevity of reporting history compared to other areas of disclosure; ii) mandatory reporting on carbon emissions, and: iii) the development of methodologies for some indirect environmental impacts. GRI has focused disclosure on environmental impact, and environmental topics account for half of those analysed here. This result suggests that, on average, companies have not advanced beyond selective and partial disclosure on environmental impacts. Whilst the average boundary setting provides a disparaging overview of approaches to sustainability reporting, analysis of topic-by-topic boundaries revealed stark variations, as detailed next.

\section{Analysis of Topic Boundaries}

GRI (2016) recommends that boundaries should be established on a topic basis. One way to interpret this might be to adopt a single boundary for ECON, another for SOCIETY and so forth. An alternative perspective would be to individually review each of the 91 topics identified by the GRI and establish independent boundaries for each. The findings observed appear to evidence that, on average, the latter approach is adopted, as boundaries vary considerably between topics. This was confirmed by the correlation analysis which was conducted to explore how strongly variables were related to each other (Table 4). This highlighted that $63 \%$ 
of the variance in RIGHTS and $58 \%$ of the variance in ENVIRN is explained by LABOUR but for all other instances the correlation is weak, albeit positive, implying that the FTSE100 adopt different boundary conditions between categories of topics, on average.

\title{
[Insert Table 4 here]
}

There was limited evidence that corporations adopt wider boundaries for material issues, and narrower boundaries for less material issues, as evident from sector-by-sector analysis of the data. For example, 2 key issues for the mining sector are 305-6(EN20) 'Emissions of ozone-depleting substance' and 304-2(EN12) 'Significant impacts on biodiversity'. None of the seven FTSE100 mining companies reported on emissions of ozonedepleting substance, despite EU endorsement of the 2016 Kigali Amendment to the Montreal Protocol, which outlined a global phase-down of hydrofluorocarbons (HFCs) (subsequently ratified on 27/9/18). In contrast the pharma group, AstraZeneca provided a good example of proactive ascriptive bounding (Ryen and Silverman, 2000) with regards to this impending legislation:

\begin{abstract}
"we included emissions from patient use of pMDI inhaler therapy products in our operational GHG footprint commitments for the first time. We believe we should account for these emissions and find innovative ways to minimise them. We continue to explore practical opportunities to reduce the climate impact of these devices while fulfilling patient needs, such as by substituting the propellant for an alternative with a lower climate impact. Research is ongoing to assess the feasibility of technologies that could potentially lower the impact of our inhaler technologies." AstraZeneca (2016:58).
\end{abstract}

The boundary adopted for 304-2(EN12) varied. There was no disclosure of this issue by Antofgasta, BHP Billiton and Rio Tinto. This result reflects the findings observed by Ringham and Miles (2018) from the aviation sector with regards to a narrow boundary construct for key areas of impact: noise pollution and $\mathrm{CO}_{2}$ emissions. Glencore provided comprehensive examples of its biodiversity and management plans:

"Two offset areas are the Newlands Nature Refuge in central Queensland (4,363 ha) and the Hillcrest area in New South Wales (1,392 ha). Both contain ecologically significant flora and endangered fauna species, offsetting disturbance from our operations and providing high quality native habitats. At Prodeco in Colombia our offset programme includes the restocking of native fish species in the La Pacha and Mata de Palma wetlands. It also involves marine ecosystem restoration for the benthos communities associated with the Banco de las Ánimas in Magdalena. We are working with the government to design a programme for the restoration, conservation and protection of the Toribio estuary mangrove ecosystem in Magdalena. We are also developing programmes for conservation and restoration of forests near the Toribio river and the Tucuy-Calenturitas river basin in Cesar." (Glencore, 2016:72)

This was coded as reputation management as it was not clear the extent to which the biodiversity and management plans covered all operations under control or ownership or the extent to which this was informed by stakeholder engagement. This contrasts with the ownership and control approach adopted by Fresnillo and Randgold, which extended biodiversity to all operations. AngloAmerican was the only mining company that extended the boundary on 304-2(EN12):

"Where significant biodiversity risks or opportunities are identified, partnerships and collaboration with local stakeholders ensure that the ecological 
considerations and community needs are addressed through the implementation of stand-alone biodiversity action plans (BAPs). A total of 31 operations have BAPs in place". (AngloAmerican, 2016:55).

This was not classified as a stakeholder engagement boundary because stakeholder engagement was restricted to those biodiversity risks and opportunities that were identified by management in the first instance.

The two topics with the widest boundary selected, on average, were 409-1(HR6) 'Operations with risks for incidents of forced or compulsory labour' $(0.4275 \pm 0.3083)$ and 305-

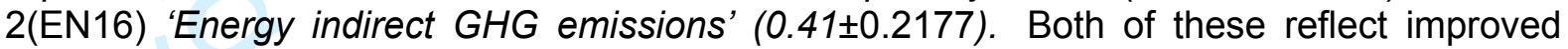
disclosure requirements of UK regulation. The Modern Slavery Act (2015), as aforementioned, requires an assessment of forced labour risks across operations and the supply chain and The Companies Act 2006 (Strategic Report and Directors' Report) Regulations 2013 called for improved carbon disclosure. Whilst $43 \%$ reported under an accountability boundary for modern slavery, a significant minority did not disclose $(n=22)$ or responded in a cherry-picked or self-laudatory manner $(n=28)$. One example of an accountability boundary for modern slavery was evident at BT Group which were instrumental in setting up the UK Modern Slavery helpline, audited their supply chain for compliance against BT's modern slavery statement and provided training not only to their own employees but also to suppliers on how to spot and react to modern slavery. Likewise British Land extended supplier audits to tier 2 suppliers. Few companies identified breaches or stakeholder engagement activities to ensure compliance. An example of good practice was identified at Diageo, which was classified as an accountability based boundary for this topic:

"Our review of Diageo-commissioned supplier audits (70) raised four issues of non-compliance related to the SMETA audit section 'employment is freely chosen'. Two of these issues related to suppliers keeping original documents belonging to employees rather than photocopies; and two related to employees being required to pay for uniforms. At the time of writing, these issues of noncompliance were outstanding, and we are following up with the suppliers to resolve them". (Diageo, 2016 p58)

This contrasted with Hikma Pharmaceuticals (classified as reputation management), which although outlining a statement of intent demonstrated no evidence of how due diligence was ensured, whether periodic analysis constituted supplier audits or the extent of the roll out of training:

"Hikma is committed to ensuring that 'modern slavery' in the form of forced or compulsory labour and human trafficking does not take place in any of its businesses or supply chains across the globe. Key measures in support of this goal include training Hikma staff on labour standards and how to recognise and respond to any incidences of modern slavery, undertaking periodic analysis and management of any modern slavery risk in Hikma's businesses or supply chains, carrying out appropriate due diligence and engaging on the issue with supply chain partners" (Hikma, 2016:6).

For GHG emissions the majority of the FTSE100 selected ownership and control boundaries $(n=72)$. This may be because CDSB (2015) did not mandate the provision of quantitative information for scope 3 emissions which 'originate outside the organization's reporting boundary as a result of contractual or other relationships between the reporting organization and third parties' (CDBS, 2015:22). It was apparent that there remains limited reporting of scope 3 emissions despite estimates that scope 3 emissions account for $75 \%$ of the carbon footprint for two thirds of industry sectors (Matthews et al., 2008, cited in Antonini and Larrinaga, 2017). Hikma justified a narrow boundary: 


\begin{abstract}
"Joint ventures with less than 50\% holding have been excluded from our GHG disclosure as it is considered that we do not have operational control over these emissions sources. In addition, non-manufacturing facilities with less than 100 staff at the end of the reporting period are not included within our emissions disclosure on the grounds of materiality". (Hikma, 2016:13)
\end{abstract}

The development of accounting methodologies has facilitated selective reporting on an extended accountability boundary for GHG emissions but only six companies achieved this (Johnson Matthey, RELX, Glencore, Royal Dutch Shell, Intu Properties and Land Securities Group), by reporting on commuter pollution by the workforce or business travel emissions, for example:

"Scope 3 business travel data is collected through our travel provider, BCD, and covers $90 \%$ of our operations by revenue. We use the Radiative Forcing (RF) emissions factors provided by the UK Department for Environment, Food \& Rural Affairs for calculating business travel emissions which take account of the full environmental impact of air travel (such as water vapour, contrails, nitrogen and oxide emissions)" (RELX, 2016:61).

There were no topics for which an accountability boundary was reflected on average across the FTSE100. For five environmental topics (305-7(EN21) NOx, SOx, and other significant air emissions; 306-3(EN24) significant spills; 306-4(EN25) hazardous waste; 3065(EN26) water discharge and (304-4(EN14) impact on IUCN red list species) no instances of an accountability boundary were observed. For $78 \%$ of topics less than a fifth of the FTSE 100 reported using an accountability boundary. In total only 466 specific disclosures were coded as representing an accountability boundary out of a potential $4900(9.51 \%)$.

There were no instances of a stakeholder engagement boundary reported, despite 23 corporations publishing a stakeholder matrix and a further 14 providing lists of stakeholder issues and engagement methods. Figure 3 provides an overview of the average disclosure across all $49 \mathrm{GRI}$ topics. Only $27 \%(\mathrm{n}=13)$ of topics were, on average, reported using an ownership and control boundary, with the $71 \%$ of topics (35/49) reported, on average, according to a reputation management boundary.

\title{
[Insert figure 3 here]
}

The narrowest boundary setting was recorded for 414.2(SO10) 'Impacts on society in the supply chain and actions taken'. This was mostly omitted by the FTSE100 resulting in an average boundary construct of $0.035 \pm 0.1508$. This finding masks accountability approaches by United Utilities, Imperial Brands, Kingfisher and Unilever, providing examples of good practice. The two topics that were most frequently reported under a reputation management boundary are 203-3(EC8) 'Indirect Economic Impacts' (n=61) and 413-1(SO1) 'Implementation of community engagement, impact assessment and development plans' $(n=52)$. Analysis showed a propensity for companies to focus on selected examples of charitable giving (e.g. Intertek, ITC, Legal and General, Travis Perkins) or employee volunteering schemes (e.g. London Stock Exchange, RELX, SSE). Some corporations stretched this to paying taxes (e.g. RBS, Vodafone), paying suppliers (Rio Tinto) or taking credit for consumer spending at adjacent businesses (Intu Properties). Some wider accountability boundaries were evident (203-3(EC8) $n=11 ; 413-1(S O 1) n=7)$. For example, Unilever detailed policies for enhancing the livelihood for small scale retailers and small holder farms, whereas Diageo outlined community activities that facilitate student learning and female empowerment. 


\section{Corporate Boundary Setting}

The widest boundary across the greatest number of topics was adopted by Unilever (UK), with $33 / 49$ topics reported on an accountability boundary. This was significantly higher than other organisations, with AstraZeneca $(n=24)$, Kingfisher $(n=19)$ and Mondi $(n=18)$ being the next highest. $65 \%$ of the FTSE100 adopted an accountability boundary for 5 or less topics. Corporations were ranked according to average boundary disclosure. Only two organisations adopted an accountability boundary on average across all topics reviewed: Unilever $(0.5654 \pm 0.2980)$ and Mondi $(0.5365 \pm 0.2247)$. Figure 4 illustrates that the boundary decisions varied considerably across topics, both within, and between the organizations, reflecting industry differences over material issues for stakeholders. The remaining corporations identified as top ten for extending the boundary of reporting, on average, adopted ownership and control boundaries (0.6387-0.4895).

\section{[Insert figure 4 here]}

Ownership and control boundaries were embraced on average by 26 FTSE100 companies. The majority $(n=72)$ implemented reputation management boundaries, with average disclosure indices ranging from $0.0313-0.2495$. The poorest reporters were Himka Pharmaceutical $(0.0313 \pm 0.0982)$, PaddyPower Betfair $(0.05 \pm 0.0947)$ and Wolseley $(0.0501 \pm 0.0948)$ (see table 5).

\section{[Insert table 5 here]}

For the bottom ten ranked organisations only Admiral provided any disclosure under an accountability boundary, which was in relation to 305-3(EN17) 'other indirect GHG emissions (scope 3)'. With the exception of Hikma Pharmaceuticals all of the bottom ten are service based companies. Service sectors were generally poor in extending the reporting boundary, with no service company ranked higher than 32. Significant differences exist between worst and best in sector, for example, Aviva (ranked 41/100) has a boundary index of $0.2106 \pm 0.2703$ compared to a range of $0.0666-0.00734$ for Admiral, RSA Insurance and St James's Place. Whilst Aviva still represents a reputation management boundary its sustainability reports could be benchmarked as a first step to improve sustainability disclosure of the other insurers. For bench-marking purposes the best-in-sector organizations for the other companies ranked within the bottom 10 are AstraZeneca (pharmaceuticals and biotech) ranked $3^{\text {rd }}(0.4790 \pm 0.3215)$, Carnival (Travel \& Leisure) ranked $32^{\text {nd }}(0.2398 \pm 0.223)$, Bunzl (Support Services) ranked $35^{\text {th }}(0.2355 \pm 0.2861)$ and $3 \mathrm{i}$ Group (financial) ranked $39^{\text {th }}$ $(0.2168 \pm 0.2380)$.

\section{Discussion}

The empirical analysis provides a disheartening picture of boundary setting within the FTSE100. The majority of FTSE100 companies $(n=72)$ on average followed a reputation management boundary indicating that the theories with greatest predicative ability over sustainability reporting boundaries are impression management (Hooghiemstra, 2000; Michelon, 2011; Colleoni, 2013; Othman et al., 2011, Pérez, 2015), risk management (Bebbington et al., 2008), signalling theory (Karasek and Bryant, 2012) and legitimacy theory (Deegan, 2002). This supports claims that current sustainability reporting fails to act as a vehicle to discharge accountability, as it is subject to managerial capture (e.g. Burritt and Schaltegger; 2010; Henri and Journeault, 2010; Joseph, 2012; Milne and Gray, 2013; Spence et al., 2010). This finding is dispiriting as sacrificing accountability to the pursuit of self-interest is to shun responsibility (Shearer, 2002), reduce the usefulness of reports and has moral implications (Francis, 1990). 
Reputation management is further evidence by the observation that 13 FTSE100 companies published stakeholder matrices or lists of stakeholder engagement activities whilst concurrently reporting under very narrow reputation management boundaries (e.g. Hikma, RSA Insurance and Shire). This may be due to a misinterpretation of materiality, given that materiality is a malleable concept influenced by heterogeneous 'logics' (Edgley et al., 2015), or it may be a deliberate attempt to mislead, for example to 'legitimately' exclude sustainability impacts having less than a 10\% impact on profits (as determined by a market logic) regardless of the impact on stakeholders. There is no guarantee of consistency between boundary setting and selected logic given the lack of regulation and guidance. It is unlikely that the requirement to define material logics would provide a solution given the boundary gap evident between average boundary definitions (ownership and control) and boundary constructs (reputation management) found.

Support was demonstrated for the economic theories of rationalism (transaction cost theory, agency theory and property rights theory) as evidenced by 26 FTSE100 companies adopting, on average, ownership and control boundaries. Some advantages to the adoption of sustainability reporting boundaries based on rationalism have been suggested, such as providing operational guidance and facilitating benchmarking (Pesci and Andrei, 2011). Nevertheless the adoption of an ownership and control boundary has mainly faced criticism. Antonini and Larrinaga (2017), for example, argued that this ignores activities outside of the consolidated group and, if left unchallenged, could lead to an institutionalization of a partial account of organizational sustainability, particularly in a world characterised by increased levels of outsourcing to less-sustainable, less-developed countries.

There should be significant reservations over the logic of basing sustainability reporting boundaries on rationalism. Firstly rationalism is based on the logic of reducing the cost of economic transactions. Sustainability reporting is concerned with a variety of measurement concepts and non-financial performance indicators. Financial reporting data collection systems are inadequately suited to measure pollution impacts or upstream and downstream data, which may be difficult or impossible to quantify due to the nebulous and intangible nature of impacts or the availability of appropriate measurement methodologies (GRI, 2005; Ringham and Miles, 2018). Transaction cost theory would infer that such impacts should be assigned beyond the organizational boundary due to cost considerations of data collection. Consequently reporting boundaries would only be extended where measurement protocols are widely, and cheaply, available, as in the reporting of indirect GHG emissions in the supply chain (scope 3) for GHG emission (CDSB, 2015), and/or elements in which data is already gathered for mandatory reasons, such as compliance with the Modern Slavery Act (2015). Secondly externalities produced by organizations extend beyond the legal boundaries of financial reporting. Morally companies should take some responsibility for upstream and downstream impacts on a range of non-financial stakeholders and this requires a widening of the boundary for disclosure.

Despite such concerns the widespread adoption of an ownership and control boundary would represent an advancement on current practice for the majority of the FTSE100. This is because this boundary construct encompasses reporting of all sustainability impacts of the entire group of companies falling under financial or operational control, or significant influence, rather than cherry-picking favourable stories for disclosure.

Contingency and systems theory are good predictors of boundary setting for the 'leaders of the pack'. Only Unilever and Mondi followed an accountability boundary on average across the 49 topics evaluated. Topic-by-topic analysis provides further support for contingency and systems theory, as evidenced by a further 9 companies disclosing more than a third of topics on an accountability boundary (Astrazeneca, Diageo, Relx, Kingfisher, Sainsburys, WPP, BAT, GSK and Vodafone). Overall there was a lack of consideration of stakeholder influences from the external environment, as evident by just $9.7 \%$ of disclosures observed to align with an accountability boundary. 
There were no practical examples to support the network theory approach (Powell, 1990 ) to the establishment of sustainability reporting boundaries, despite this forming the framework for AA1000 (2018). Only 37 FTSE100 companies disclosed stakeholder engagement information, such as the creation of a stakeholder materiality matrix, or a list/table of material issues and engagement channels, however there was a disconnect between the stakeholder engagement examples given and the boundary drawn, particularly for those reporting under a reputation management boundary. There were a number of examples that were considered close to a stakeholder engagement boundary, but fell short for a variety of reasons. This was due to extending the boundary for selective examples, such as: focusing on one product (e.g. Diageo detailed life cycle assessments for Smirnoff (EN30)); one feature of the supply chain (e.g. Kingfisher addressed comprehensive supply chain risks for timber sourcing (EN32)); one geographical region (e.g. Next focused on Latin America and South East Asia for supplier audits in $3^{\text {rd }}$ parties), or; one area of emissions (e.g. Mondi provided a very wide ranging discussion of scope 3 emissions (EN17) including employee commuting and business travel but ignored emissions associated with, for example, capital infrastructure). There were also examples of boundaries being extended proactively to forestall, or prepare for, regulatory intervention, rather than as a result of stakeholder engagement, e.g. GSK and AstraZeneca's discussion of inhaler propellants as ozone depleting substances (EN20). As such this relates to ascriptive bounding rather than reciprocal bounding (Ryen and Silverman, 2000) associated with stakeholder engagement.

\section{Conclusions}

The aim of this paper is to use a multidisciplinary theoretical understanding of boundary setting to develop a quadripartite model in which sustainability reporting boundaries are classified as 'Reputation Management', 'Ownership and Control', 'Accountability; and, 'Stakeholder Engagement'. Understanding of boundary setting was derived from an analysis of social constructionism and multi-disciplinary theoretical perspectives including impression management theory, economic theories of rationalism, systems theory, contingency theory, and network theory. Prior academic analysis of this meta-level concept is scant, prompting a need for further research to fully understand how decisions over boundary construction help, and hinder, accountability. Viewing boundary construction from a range of multidisciplinary perspectives has enabled a theory-informed advancement in thinking of boundary setting within sustainability reporting, which was previously viewed as dichotomous (organisational/operational) (Antonini and Larrinaga, 2017; Archel et al., 2008) or tripartite (reputation management, ownership and control and accountability) (Ringham and Miles, 2018).

The model was empirically tested on sustainability reporting by the FTSE100. Practical examples of reporting boundaries were observed across 3 boundary classes. The findings provide conclusive and significant $(p<0.0001)$ evidence of the narrow, reputation management boundaries adopted by the majority $(72 \%)$ of the FTSE 100 , confirming a more egregious status quo than previously observed by Archel et al., (2008) and Ringham and Miles (2018).

The significant majority of sustainability research employs legitimacy theory and stakeholder theory to explain voluntary sustainability disclosure. The findings suggest alternative perspectives should be explored as impression management, risk management and reputation management (e.g. Colleoni, 2013; Hooghiemstra, 2000; Michelon, 2011; Othman et al., 2011; Pérez, 2015) have greater explanatory power with respect to the construction of sustainability reporting boundaries. To a lesser extent the economic theories of rationalism provide some predictive ability for the top quartile of reporters. Analysing motivations for voluntary disclosure from alternative perspectives provides greater insight into, 
and understanding of current practice, leading to enhanced theory and more informed solutions to improve sustainability disclosure and practice.

Previous research has criticised the adoption of an ownership and control boundary for sustainability reporting (Antonini and Larrinaga, 2017; Gray, 2006; Kaspersen, 2013; Ringham and Miles, 2018) and whilst we share these concerns this represents an advancement in practice for the majority of the FTSE100, and should therefore be encouraged. Very limited evidence was found to support contingency theory and systems theory, with less than $10 \%$ of total disclosures representing an extended accountability boundary. No current examples of the network theory informed stakeholder engagement boundary were identified. This finding may be indicative of a lack of associated methodologies to capture indirect impacts on corporate stakeholders. Given that the FTSE 100 index covers some of the largest, high profile companies in the world, facing the greatest levels of stakeholder pressure for disclosure, generalisation of these findings across other stock exchanges, or to smaller companies would suggest a disheartening picture of sustainability disclosure based on reputation management.

The findings reveal several issues for reporting practice. Prior research examining reporting content quality or motivations for voluntary disclosure has suggested that sustainability reporting is largely unfit for purpose and subject to management capture (e.g. Bebbington and Larrinaga, 2014; Burritt and Schaltegger, 2010; Henri and Journeault, 2010; Joseph, 2012; Milne and Gray, 2013, and; Spence et al., 2010). The review of boundary setting confirm these findings. In addition evidence presented demonstrates that $62 \%$ of the FTSE100 provided misleading definitions of sustainability reporting boundaries based on ownership and control, given that the average boundary applied was based on reputation management. In line with Antonini and Larrinaga (2017) we advocate that standard setters require companies to define boundaries with precision and to justify the approach adopted, including evidence-based examples to illustrate how boundary setting has been applied to avoid duplicity.

Regulation has an important role to play. The Modern Slavery Act (2015) and The Companies Act (2006) has widened boundaries under 409-1(HR6) 'Operations with risks for incidents of forced or compulsory labour' $(0.4275 \pm 0.3083$ ) and 305-2(EN16) 'Energy indirect GHG emissions' (0.41 \pm 0.2177$)$. Some evidence was found of early adoption of the 2016 Kigali Amendment to the Montreal Protocol in regards to HFCs. Future regulation could target areas of political concern, such as single-use plastic waste, obesity, deforestation, or climate change, to widen accountability through boundary setting.

Defining boundaries on a topic-by-topic basis is appropriate as this encourages different sectors to identify the most relevant topics, and to reach agreement on the form the boundary of reporting might take. To ensure application of a wider boundary for material topics a stakeholder logic must be applied in the determination of materiality. Ranking of the FTSE100 highlights best and worst practice and facilitates benchmarking to improve practice. This could also be used in a 'name and shame' campaign by government, or as a focus for stakeholders to pressure laggards to improve accountability, for example if they fall within the bottom quartile. Radar graphs are presented for the top ten reporters to enable stakeholders to identify examples of best practice on specific topic boundary setting or to target stakeholder engagement or activism more effectively. If this exercise was replicated year-on-year an index of sustainability reporting boundary could be created. This could be used by the financial community as an indicator of the quality of corporate governance and risk management: two key factors that influence share price.

Sustainability reporting offers a means in which trust can be fostered through building a stronger relationship between stakeholder engagement and the determination of reporting content and boundary drawing. The empirical findings reveal that management are failing to 
engage substantively with stakeholders in the determination of reporting boundaries. There is evidence of the publication of stakeholder materiality matrices and lists of engagement topics but this is not reflected in the boundary approach adopted. Given this duplicity correlation analysis could be undertaken to determine the (non) extent to which stakeholder matrices determine disclosure or the existence of pseudo-stakeholder consultation. This line of enquiry could also be explored through an in-depth analysis of sector disclosure, in light of sector-specific material impacts and boundaries specified and adopted. There is an unchallenged assumption that narrow boundary setting is correlated to poor quality disclosure. This is easily testable and could also be the subject of future research. The sustainability reporting analysed was captured at a point in time and so presents a snapshot of reporting practice. The methods followed are clearly disclosed permitting replication of approach in future studies wishing to track FTSE100 progress over time, or to explore alternative context to the FTSE100, such as boundary setting with the public sector, or regional/cultural differences to boundary setting. There is also further scope to examine in more depth boundary setting within industry sectors or to examine motivations to boundary setting through questionnaire or interview approaches.

There are limitations to this research. The use of the GRI may been seen as an inherent limitation given that it seeks to provide a framework for all types of organisations and has been criticised for leading to a box ticking approach to satisfy compliance (de Colle et al., 2014; Jamali, 2010). Its structure may, therefore, be fundamental in the adoption of narrow boundaries. The GRI framework is used instrumentally to identify disclosure topics: had we developed our own disclosure framework we may have identified disclosure topics and provided an alternative perspective on boundaries observed. Whilst the results are more generalizable than previous research due to the sample size and coverage of disclosure topics, we acknowledge the restriction of generalizability to large publicly listed companies: other ownership models (public sector, employee owned, co-operative) are likely to reveal further insights. It is also possible that companies operating in more confined geographical areas will have different boundaries as they respond to different external expectations.

\section{References}

AA1000 (2018), "Accountability Principles 2018", available at: https://www.accountability.org/standards/ (accessed 17 August 2018)

AngloAmerican (2016), "Sustainability Report", available at: https://www.angloamerican.com/ /media/Files/A/Anglo-American-PLCV2/documents/annual-reporting-2016/downloads/2016-sustainability-report.pdf (accessed 17 August 2018)

Admiral (2016), "Corporate Social Responsibility Report”, available at: https://do354dnzymf0.cloudfront.net/sites/default/files public/Admiral\%20CSR\%20R eport\%202016.pdf (accessed 18 August 2018)

Antonini, C. and Larrinaga, C. (2017), "Planetary boundaries and sustainability indicators: A survey of corporate reporting boundaries", Sustainable Development, Vol. 25, pp.123-137.

Archel, P., Fernández, M., and Larrinaga, C. (2008), "The organizational and operational boundaries of triple bottom line reporting: a survey", Environmental Management, Vol. 41, pp.106-117.

Ashkenas, R., Ulrich, D., Jick, T. and Kerr, S. (1995), The Boundaryless Organisation, Jossey-Bass, San Francisco.

Associated British Foods (2016), "Doing Good Every Day: Corporate Responsibility Report", available at: https://www.abf.co.uk/responsibility (accessed 3 January 2018). 
AstraZeneca (2016), "Securing our Future: Our Sustainability Journey", available at: https://www.astrazeneca.com/content/dam/az/Sustainability/55229\%20AZ Our\%20S ustainability\%20Journey AW6 V2.pdf (accessed 22 October 2019)

Banerjee, S.B. (2003), "Who Sustains Whose Development? Sustainable Development and the Reinvention of Nature", Organization Studies, Vol. 24 No. 1, pp.143-80.

Bavagnoli, F., Comoli, M., Gelmini, L. and Riva, P. (2014), "An open question in the Integrated Reporting: Materiality or conciseness?", available at: https://papers.ssrn.com/sol3/papers.cfm?abstract_id=2508657 (accessed 21 February 2018).

Bebbington, J., Larrinaga, C., and Moneva, J.M. (2008), "Corporate social reporting and reputation risk management", Accounting, Auditing \& Accountability Journal, Vol. 21 No.3, pp.337-361.

Burritt, R., and Schaltegger, S. (2010), "Sustainability accounting and reporting: fad or trend?" Accounting, Auditing \& Accountability Journal, Vol. 23 No. 7, pp.829-846.

CDSB (2013), "Communicating Climate Change in Mainstream Reports", available at: http://www.cdsb.net/sites/cdsbnet/files/cdsbframeworkguidev1 0 2.pdf (accessed 25 January 2018)

CDSB (2015), "Framework for reporting environmental information \& natural capital", available at:

http://www.cdsb.net/sites/cdsbnet/files/cdsb framework for reporting environmental information natural_capital.pdf (accessed 25 January 2018)

Chua, W.F. and Mahama, H. (2007), "The effect of network ties on accounting controls in a supply alliance: field study evidence", Contemporary Accounting Research, Vol.24 No. 1, pp.47-86.

Colleoni, E. (2013), "CSR communication strategies for organizational legitimacy in social media", Corporate Communications: An International Journal, Vol. 18 No. 2, pp.228248.

Companies Act (The) (2006), "(Strategic Report and Directors' Report) Regulations 2013", available at: https://www.legislation.gov.uk/ukdsi/2013/9780111540169/pdfs/ukdsi 978011154016 9 en.pdf (accessed 5 April 2018)

de Colle, S., Henriques, A. and Sarasvathy, S. (2014), "The Paradox of Corporate Social Responsibility Standards", Journal of Business Ethics, Vol. 125 No. 2, pp.177-191.

Deegan, C. (2002), "The legitimising effect of social and environmental disclosures - a theoretical foundation", Accounting, Auditing \& Accountability Journal, Vol. 15 No. 3, pp.282-311.

Diageo (2016), Sustainability \& Responsibility Performance available at: https://www.diageo.com/en/investors/financial-results-andpresentations/sustainability-responsibility-performance-addendum-2016/ (accessed 17 October 2018)

Dyer, J.H. and Nobeoka, K. (2000), "Creating and Managing a High-Performance Knowledge-Sharing Network: The Toyota Case", Strategic Management Journal, Vol. 21 No.3, pp.345-367.

Edgley, C., Jones, M.J., and Atkins, J. (2015), "The adoption of the materiality concept in social and environmental reporting assurance: A field study approach", The British Accounting Review, Vol.47, pp.1-18.

Egels-Zandén, N. (2017), "Responsibility Boundaries in Global Value Chains: Supplier Audit Prioritizations and Moral Disengagement Among Swedish Firms", Journal of Business Ethics, Vol. 146, pp. 515-528.

Flower, J. (2015), "The International Integrated Reporting Council: A story of failure", Critical Perspectives on Accounting, Vol. 27, pp.1-17.

Fombrun, C.J.; Gardberg, N.A. and Barnett, M.L. (2000), "Opportunity platforms and safety nets: Corporate citizenship and reputational risk", Business and Society Review, Vol. 105 No. 1, pp.85-106. 
Francis, J.R. (1990), "After virtue? Accounting as a moral and discursive practice", Accounting, Auditing \& Accountability Journal, Vol. 3 No.3, pp.5-17.

Friedman, A.L. and Miles, S. (2001), "Socially responsible investment and corporate social and environmental reporting in the UK: an exploratory study", British Accounting Review, Vol. 33, pp.523-548.

Friedman, A.L. and Miles, S. (2006), Stakeholders: Theory and Practice, Oxford University Press: Oxford.

Galbraith, J. (1977), Organization design. Reading, MA: Addison-Wesley.

Glencore (2016) Sustainability Report available at: https://www.glencore.com/dam/jcr:61aaaf30-3d39-4c2d-a642-0ed8f908b58b/2016Glencore-Sustainabilty-Report.pdf (Accessed 15 August 2018)

Gowthrope, C. (2009), "Wider still and wider? A critical discussion of intellectual capital recognition, measurement and control in a boundary theoretical context", Critical Perspectives on Accounting, Vol. 20, pp.823-834.

Grandori A. (2000), Organization and Economic Behaviour, Routledge, London.

Gray, R. (2006), "Social, environmental and sustainability reporting and organizational value creation? Whose value? Whose creation?" Accounting, Auditing \& Accountability Journal, Vol. 19, pp.793-819.

GRI (2000), "Sustainability Reporting Guidelines", Global Reporting Initiative: Boston MA.

GRI (2005), "GRI Boundary Protocol”, Global Reporting Initiative: Amsterdam NL.

GRI (2011), "Sustainability Reporting Guidelines v.3.1”, Global Reporting Initiative: Amsterdam NL.

GRI (2013), "Sustainability Reporting Guidelines, v.4", Global Reporting Initiative: Amsterdam NL.

GRI (2016), “Consolidated Sustainability Reporting Guidelines 2016”, Global Reporting Initiative: Amsterdam NL.

Henri, J.-F., and Journeault, M. (2010), "Eco-control: The influence of management control systems on environmental and economic performance", Accounting, Organizations \& Society, Vol. 35 No. 1, pp.63-80.

Heracleous, L. (2004), "Boundaries in the study of organization", Human Relations, Vol. 57 No. 1, pp.95-103.

Hernes, T. (2004), "Studying composite boundaries: A framework of analysis", Human Relations, Vol. 57 No. 1, pp.9-29.

Hikma (2016), "Building for the Future", available at: https://www.hikma.com/media/1439/2016-sustainability-report.pdf (accessed 15 April 2018)

Hines, R. (1988), "Financial accounting: in communicating reality we construct reality", Accounting Organizations and Society, Vol. 13, pp.251-262.

Hooghiemstra, R. (2000), "Corporate Communication and Impression Management - New Perspectives Why Companies Engage in Corporate Social Reporting", Journal of Business Ethics, Vol. 27 No. 1-2, pp 55-68.

IASB (2010), The Conceptual Framework for Financial Reporting 2010, IFRS Foundation, London

IASB (2018), The Conceptual Framework for Financial Reporting 2018, IFRS Foundation, London

IIRC (2013), "The International <|R> Framework", available at: at: http://www.theiirc.org/international-ir-framework/ (accessed on 20 February 2018)

Intercontinental Hotel Group (2016), "2016 Responsible Business Report", available at: https://www.ingplc.com/-/media/ihg/files/responsible-business/2018-responsiblebusiness/downloads/2016/2016 ing responsible business report.pdf (accessed 2 January 2018)

Jamali, D. (2010), "MNCs and international accountability standards through an institutional lens: Evidence of symbolic conformity or decoupling", Journal of Business Ethics, Vol. 95 No. 4, pp.617-640. 
Joseph, G. (2012), "Ambiguous but tethered: An accounting basis for sustainability reporting", Critical Perspectives on Accounting, Vol. 23 No. 2, pp. 93-106.

Karasek, R. and Bryant, P. (2012), "Signalling theory: Past, present and future", Academy of Strategic Management Journal, Vol. 11 No. 1, pp.91-99.

Kaspersen, M. (2013), "The construction of social and environmental reporting", PhD Series 11.2013, Copenhagen Business School: Copenhagen.

Kaspersen, M. and Johansen, T. (2016), "Changing social and environmental reporting systems", Journal of Business Ethics, Vol. 135 No.4, pp.731-749.

Katz, D. and Kahn, R. (1966), The Social Psychology of Organizations, Wiley, New York,

KPMG (2017), "The Road Ahead: The KPMG Survey of Corporate Responsibility Reporting 2017", available at: https://home.kpmg/content/dam/kpmg/campaigns/csr/pdf/CSR Reporting 2017.pdf (accessed 10 April 2018)

Lamberton, G. (2005), "Sustainability accounting - a brief history and conceptual framework", Accounting Forum, Vol. 29, pp.7-26.

Llewellyn, S. (1994), "Managing the boundary: How accounting is implicated in maintaining the organization", Accounting, Auditing \& Accountability Journal, Vol. 7, pp.4-23.

Lowe, A. (2001), "'Action at a distance': accounting inscriptions and the reporting of episodes of clinical care", Accounting Forum, Vol.25, pp. 21-55.

Luhmann, N. (1995), Social Systems, Stanford University Press, Stanford, CA.

MacDonald, K. (2011), "Re-thinking 'spheres of responsibility': Business responsibility for indirect harm", Journal of Business Ethics, Vol. 99, pp.549-563.

Michelon, G. (2011), "Sustainability disclosure and reputation: A comparative study", Corporate Reputation Review, Vol. 14 No. 2, pp.79-96.

Milne, M. and Alder, R. (1999), "Exploring the reliability of social and environmental disclosures content analysis", Accounting, Auditing and Accountability Journal, Vol. 12, pp.237-256.

Milne, M., and Gray, R. (2013), "W(h)ither Ecology? The Triple Bottom Line, the Global Reporting Initiative, and corporate sustainability reporting", Journal of Business Ethics, Vol. 118 No. 1, pp.13-29.

Milne, M., Kearins, K., and Walton, S. (2006), "Creating adventures in wonderland: the journey metaphor and environmental sustainability", Organization, Vol. 13 No. 6, pp.801-839.

Milne M., Tregidga H., Walton S. (2009), "Words not actions! The ideological role of sustainable development reporting", Accounting Auditing and Accountability Journal, Vol. 22 No. 8, pp.1211-1257.

Mitchell, R.K., Agle, B.R. and Wood, D.J. (1997), "Towards a theory of stakeholder identification and salience: Defining the principle of who and what really counts". Academy of Management Review, Vol. 22, pp.853-886.

Modern Slavery Act (2015), c.30, available at: http://www.legislation.gov.uk/ukpga/2015/30/pdfs/ukpga 20150030 en.pdf (accessed on 10 April 2018)

Morgan, G. (1986), Images of Organizations, Sage, London.

Othman, S.; Darus, F. and Arshad, R. (2011), "The influence of coercive isomorphism on corporate social responsibility reporting and reputation", Social Responsibility Journal, Vol. 7 No. 1, pp.118-135.

Pérez, A. (2015), "Corporate reputation and CSR reporting to stakeholders: Gaps in the literature and future lines of research", Corporate Communications: An International Journal, Vol. 20 No. 1, pp.11-29

Pesci, C. and Andrei, P. (2011), "An empirical investigation into the boundary of corporate social reports and consolidated financial statements", Social and Environmental Accountability Journal, Vol. 31, pp.73-84.

Phillips, R.A. (1997), "Stakeholder theory and a principle of fairness", Business Ethics Quarterly, Vol. 7, pp.51-66. 
Powell, W.W. (1990), "Neither market nor hierarchy: network forms of organization". Research in Organizational Behavior, Vol. 12, pp.295-336.

RELX (2016), "Corporate Responsibility Report 2016", available at: https://www.relX.com/ /media/Files/R/RELXGroup/documents/responsibility/download-center/2016-cr-report-new.pdf (accessed 15 April 2018)

Ringham, K. and Miles, S. (2018), "CSR reporting in the airline industry: the boundary of reporting", Journal of Sustainable Tourism, Vol. 26 No. 7, pp.1043-1062.

Rodrigue, M. Magnan, M. and Boulianne, E. (2013), "Stakeholders' influence on environmental strategy and performance indicators: A managerial perspective", Management Accounting Research, Vol. 24, pp.301-316.

Ryen, A. and Silverman, D. (2000), "Marking boundaries: culture as category work", Qualitative Inquiry, Vol. 6, No. 1, pp.107-128.

Shearer, T. (2002), "Ethics and accountability: From the for-itself to the for-the-other", Accounting, Organizations and Society, Vol.27, pp.541-573.

Spence, C, Husillos, J . and Corren-Ruiz, C. (2010), "Cargo cult science and the death of politics: A critical review of social and environmental accounting research", Critical Perspectives on Accounting, Vol. 21 No. 1, pp.76-89.

Thompson, J. D. (1967), Organizations in Action, McGraw-Hill, New York.

Thornton PH, Tuma NB. (1995), "The problem of boundaries in contemporary research on organizations", Proceedings of the Academy of Management, Vol. 1, pp.276-80.

Thrane, S. and Sundtoft Hald, K. (2006), "The emergence of boundaries and accounting in supply fields: The dynamics of integration and fragmentation", Management Accounting Research, Vol.17, pp.288-314.

Tregidga, H., Milne, M. and Kearins, K. (2014), “(Re)presenting 'sustainable organizations”, Accounting, Organizations and Society, Vol. 39, pp.77-494.

UNGC (2009), 'The Practical Guide to the UN Global Compact Communication on Progress' available at:

http://www.undp.org/content/dam/turkey/docs/Publications/PovRed/Practical Guide 2008 En.pdf (accessed 2 April 2018)

Walton, P. (2006), "Fair value and executory contracts: moving the boundaries in international financial reporting" Accounting and Business Research, Vol. 36 No. 4, pp.337-343. 
Table 1: Classification of Boundary Setting within Sustainability Reporting

\begin{tabular}{|c|c|c|c|c|}
\hline Boundary Logics & $\begin{array}{c}\text { Reputation (Perception) } \\
\text { Management }\end{array}$ & Ownership and Control & Accountability & Stakeholder Engagement \\
\hline \multirow{2}{*}{$\begin{array}{l}\text { Theoretical/ } \\
\text { Ideological } \\
\text { underpinning }\end{array}$} & \multicolumn{2}{|c|}{ Rationalism; Economics; Transaction Cost Theory; Agency theory } & Strategic Stakeholder Theory & Normative Stakeholder Theory \\
\hline & $\begin{array}{l}\text { Corporate Identity Theory; } \\
\text { Legitimacy Theory; Impression } \\
\text { Management Theory; Risk } \\
\text { Management Theory; Signalling } \\
\text { theory; Social Constructionism } \\
\text { (Managerial capture); }\end{array}$ & $\begin{array}{l}\text { Property Rights theory; Social } \\
\text { Constructionism (Ascriptive bonding } \\
\text { and 'Accounting as Actant') }\end{array}$ & $\begin{array}{l}\text { Contingency Theory; Systems Theory; } \\
\text { Resource Dependency Theory; } \\
\text { Community Ecology Theory; } \\
\text { Social constructionism (strategic } \\
\text { bonding) }\end{array}$ & $\begin{array}{l}\text { Network Theory (Sociology) } \\
\text { Social constructionism (reciprocal } \\
\text { bonding) }\end{array}$ \\
\hline Permeability & Open: Cherry picked & Closed: Hard, legal & $\begin{array}{l}\text { Open: Permeable, changeable within } \\
\text { zone of influence }\end{array}$ & $\begin{array}{l}\text { Boundaryless: Amorphous, Composite, } \\
\text { Dynamic, Ephemeral }\end{array}$ \\
\hline $\begin{array}{l}\text { Environmental } \\
\text { influence }\end{array}$ & Unidirectional (Managerial capture) & $\begin{array}{l}\text { Legal and Financial reporting } \\
\text { influences }\end{array}$ & $\begin{array}{l}\text { Unidirectional (Strategic Stakeholder } \\
\text { Management) }\end{array}$ & Multidirectional (Interdependencies) \\
\hline $\begin{array}{l}\text { Accountability } \\
\text { Strategy }\end{array}$ & Defensive or Reactive & Mirrors financial reporting & Accommodative & Proactive \\
\hline $\begin{array}{l}\text { Conceptualization } \\
\text { of stakeholders }\end{array}$ & $\begin{array}{l}\text { All stakeholders are external parties } \\
\text { that can impact corporate } \\
\text { reputation and therefore need to be } \\
\text { managed. }\end{array}$ & $\begin{array}{l}\text { Inside (Management and finance } \\
\text { providers). Outside (Market place } \\
\text { including all other stakeholders) }\end{array}$ & $\begin{array}{l}\text { Inside (management, finance } \\
\text { providers). Zone of influence } \\
\text { (peripheral stakeholders). Outside } \\
\text { (All other stakeholders) }\end{array}$ & $\begin{array}{l}\text { Nexus of stakeholders. Stakeholders } \\
\text { are inside the corporate boundary and } \\
\text { can influence boundary setting. }\end{array}$ \\
\hline Boundary setting & Managerially determined & $\begin{array}{l}\text { Legally and managerially } \\
\text { determined. }\end{array}$ & Managerially determined & $\begin{array}{l}\text { Managerially and stakeholder } \\
\text { determined. }\end{array}$ \\
\hline Materiality & \multicolumn{2}{|c|}{ Market logic } & Market logic and Stakeholder logic & Stakeholder logic \\
\hline Reliability & Not relevant & Reasonable certainty & \multicolumn{2}{|c|}{ Relevance to material impacts more important than reliability } \\
\hline Orientation & Past (legitimise historic actions) & Past (re: accounting period) & \multicolumn{2}{|c|}{ Past and Future } \\
\hline $\begin{array}{l}\text { Organization vs } \\
\text { operational }\end{array}$ & Partial organizational boundary & Organizational boundary & $\begin{array}{c}\text { Organizational and partial } \\
\text { operational boundaries }\end{array}$ & $\begin{array}{l}\text { Organizational and operational } \\
\text { boundaries }\end{array}$ \\
\hline $\begin{array}{l}\text { Reporting } \\
\text { content }\end{array}$ & $\begin{array}{l}\text { Selected content: Issues requiring } \\
\text { recovery of legitimacy included in } \\
\text { reporting boundary. } \\
\text { Good news inside boundary } \\
\text { Bad news outside boundary. }\end{array}$ & $\begin{array}{l}\text { Management have discretion over } \\
\text { what is owned and controlled } \\
\text { (determined by economic } \\
\text { efficiencies and contractual } \\
\text { hazards). Transactions involving } \\
\text { uncertainty, asset specifity, inter- } \\
\text { firm dependency are internalized, } \\
\text { otherwise excluded (outsourced). }\end{array}$ & $\begin{array}{l}\text { Significant impact for salient } \\
\text { organizational and operational } \\
\text { stakeholders which may include } \\
\text { direct and indirect impact within } \\
\text { group and upstream and } \\
\text { downstream operations. }\end{array}$ & $\begin{array}{l}\text { Significant direct and indirect impacts } \\
\text { from, and on the nexus of stakeholders }\end{array}$ \\
\hline
\end{tabular}


Table 2: Interpretation of hypothetical means (and corresponding adjustments)

\begin{tabular}{llll} 
& $\begin{array}{l}\text { Dichotomous scoring } \\
\text { (Archel et al., 2008) }\end{array}$ & $\begin{array}{l}\text { Tripartite scoring } \\
\text { (Ringham and Miles, 2018) }\end{array}$ & Quadripartite scoring \\
\hline Mean & 0.4 (adjusted to 0.2) & 0.3291 (adjusted to 0.2468) & \\
\hline Not applicable & $0-0.32$ reputation management & $0-0.24$ reputation management \\
& $0-0.49$ organizational boundary & $0.33-0.65$ ownership and control & $0.25-0.49$ ownership and control \\
& $0.50-1$ operational boundary & $0.66-1$ accountability & $0.50-0.74$ accountability \\
Not applicable & Not applicable & $0.75-1$ stakeholder engagement \\
\hline
\end{tabular}


Table 3: Boundary disclosure across GRI indicators within the FTSE100: Descriptive Statistics and one-sample t-tests

Hypothetical Mean

\begin{tabular}{|c|c|c|c|c|c|c|c|c|c|c|c|c|}
\hline \multirow[b]{2}{*}{ Variable } & \multirow[b]{2}{*}{$N$} & \multirow[b]{2}{*}{ Min. } & \multirow[b]{2}{*}{ Max. } & \multirow[b]{2}{*}{ Mean } & \multirow[b]{2}{*}{$\begin{array}{l}\text { Std. } \\
\text { Dev. }\end{array}$} & \multicolumn{2}{|c|}{$\begin{array}{c}0.2 \\
\text { (Archel et al., } \\
\text { 2008) }\end{array}$} & \multicolumn{2}{|c|}{$\begin{array}{c}0.2468 \\
\text { (Ringham and } \\
\text { Miles 2018) }\end{array}$} & \multicolumn{3}{|c|}{$\begin{array}{c}\text { Category Specific } \\
\text { (Ringham and Miles 2018) }\end{array}$} \\
\hline & & & & & & $t$ & p-value & $t$ & p-value & $\begin{array}{l}\text { Hypothetical } \\
\text { mean }\end{array}$ & $t$ & p-value \\
\hline LABOUR & 100 & 0.00 & 0.75 & 0.221 & 0.192 & 1.075 & 0.2852 & 1.367 & 0.1748 & 0.267 & 2.420 & 0.0173 \\
\hline SOCIETY & 100 & 0.00 & 0.75 & 0.133 & 0.143 & 4.682 & $<0.0001$ & 7.657 & $<0.0001$ & 0.229 & 6.697 & $<0.0001$ \\
\hline RIGHTS & 100 & 0.00 & 0.71 & 0.228 & 0.183 & 1.535 & 0.1281 & 1.021 & 0.3096 & 0.319 & 4.954 & $<0.0001$ \\
\hline ECON & 100 & 0.00 & 0.70 & 0.276 & 0.176 & 4.292 & $<0.0001$ & 1.632 & 0.1059 & 0.145 & 7.430 & $<0.0001$ \\
\hline ENVIRN & 100 & 0.03 & 0.53 & 0.196 & 0.100 & 0.3804 & 0.7045 & 5.065 & $<0.0001$ & 0.221 & 2.432 & 0.0168 \\
\hline PRODUCT & 100 & 0.00 & 0.75 & 0.153 & 0.158 & 3.014 & 0.0033 & 5.984 & $<0.0001$ & $n / a$ & $n / a$ & $n / a$ \\
\hline
\end{tabular}


Table 4: Correlation Analysis and Variance $\left(\mathbf{R}^{2}\right)$ for Categories of GRI Indicators

\begin{tabular}{lrrrrrr} 
& \multicolumn{1}{l}{ LABOUR } & \multicolumn{1}{l}{ SOCIETY } & \multicolumn{1}{l}{ RIGHTS } & \multicolumn{1}{l}{ ECON } & ENVIRN & PRODUCT \\
\hline LABOUR & 1.000 & & & & & \\
SOCIETY & $0.492(24 \%)$ & 1.000 & & & & \\
RIGHTS & $0.794(63 \%)$ & $0.500(25 \%)$ & 1.000 & & & \\
ECON & $0.505(25 \%)$ & $0.505(26 \%)$ & $0.596(35 \%)$ & 1.000 & & \\
ENVIRN & $0.764(58 \%)$ & $0.624(39 \%)$ & $0.693(48 \%)$ & $0.647(42 \%)$ & 1.000 & \\
PRODUCT & $0.549(30 \%)$ & $0.519(27 \%)$ & $0.443(20 \%)$ & $0.522(27 \%)$ & $0.668(45 \%)$ & 1.000
\end{tabular}


Table 5: FTSE100 Corporate Ranking: Average Boundary Constructs adopted

\begin{tabular}{|c|c|c|c|}
\hline Company & Sector & Boundary \pm STDEV & No. boundaries $>3$ \\
\hline \multicolumn{4}{|c|}{ Accountability boundary } \\
\hline 1. UNILEVER (UK) & Food \& Beverages & $0.5654 \pm 0.2980$ & 33 \\
\hline 2. $\mathrm{MONDI}$ & Basic resource (Ex mining) & $0.5365 \pm 0.2247$ & 18 \\
\hline \multicolumn{4}{|c|}{ Ownership and Control boundary } \\
\hline 3. ASTRAZENECA & Pharmaceuticals \& Biotech & $0.4790 \pm 0.3215$ & 24 \\
\hline 4. DIAGEO & Food \& Beverages & $0.4608 \pm 0.2556$ & 15 \\
\hline 5. RELX & Media & $0.4070 \pm 0.2991$ & 16 \\
\hline 6. KINGFISHER & Retailers & $0.3938 \pm 0.3293$ & 19 \\
\hline 7. BHP BILLITON & Mining & $0.3854 \pm 0.2775$ & 11 \\
\hline 8. SAINSBURY (J) & Retailers & $0.3822 \pm 0.3057$ & 15 \\
\hline 9. UNITED UTILITIES & Utilities & $0.3671 \pm 0.2698$ & 8 \\
\hline 10. $\mathrm{CRH}$ & Construction \& Materials & $0.3665 \pm 0.2391$ & 6 \\
\hline 11. MARKS \& SPENCER & Retailers & $0.3578 \pm 0.2361$ & 5 \\
\hline 12. WPP & Media & $0.3574 \pm 0.2953$ & 12 \\
\hline 13. TAYLOR WIMPEY & House, Leisure \& Personnel & $0.3567 \pm 0.2915$ & 11 \\
\hline 14. GLENCORE & Mining & $0.3450 \pm 0.2646$ & 7 \\
\hline 15. RANDGOLD RESOURCES & Mining & $0.3411 \pm 0.3049$ & 10 \\
\hline 16. BRITISH AMERICAN TOBACCO & Tobacco & $0.3371 \pm 0.3073$ & 12 \\
\hline 17. BT GROUP & Technology & $0.3258 \pm 0.2913$ & 10 \\
\hline 18. GLAXOSMITHKLINE & Pharmaceuticals \& Biotech & $0.3231 \pm 0.3248$ & 14 \\
\hline 19. NEXT & Retailers & $0.3177 \pm 0.2996$ & 11 \\
\hline 20. RECKITT BENCKISER & House, Leisure \& Personnel & $0.3129 \pm 0.2876$ & 8 \\
\hline 21. ANTOFAGASTA & Mining & $0.3125 \pm 0.3073$ & 9 \\
\hline 22. Royal Dutch Shell & Oil \& Gas & $0.2917 \pm 0.2840$ & 8 \\
\hline 23. VODAFONE GROUP & Technology & $0.2840 \pm 0.3358$ & 13 \\
\hline 24. IMPERIAL BRANDS & Tobacco & $0.2789 \pm 0.3127$ & 11 \\
\hline 25. RIO TINTO & Mining & $0.2708 \pm 0.2518$ & 4 \\
\hline 26. SSE & Utilities & $0.2629 \pm 0.2504$ & 3 \\
\hline 27. JOHNSON MATTHEY & Chemicals & $0.2553 \pm 0.2825$ & 7 \\
\hline 28. BRITISH LAND & Real Estate & $0.2553 \pm 0.2788$ & 5 \\
\hline \multicolumn{4}{|c|}{ Reputation Management Boundary } \\
\hline 29. ROYAL MAIL & Industrial transportation & $0.2495 \pm 0.2643$ & 6 \\
\hline 30. SEVERN TRENT & Utilities & $0.2473 \pm 0.2480$ & 3 \\
\hline 31. SKY & Media & $0.2408 \pm 0.2593$ & 5 \\
\hline 32. CARNIVAL & Travel \& Leisure & $0.2398 \pm 0.2230$ & 1 \\
\hline 33. FRESNILLO & Mining & $0.2396 \pm 0.2915$ & 6 \\
\hline 34. ASSOCIATED BRIT.FOODS & Food \& Beverages & $0.2366 \pm 0.2360$ & 3 \\
\hline 35. BUNZL & Support Services & $0.2355 \pm 0.2861$ & 7 \\
\hline 36. BP & Oil \& Gas & $0.2344 \pm 0.2890$ & 6 \\
\hline 37. ROLLS-ROYCE HOLDINGS & Aerospace \& defence & $0.2240 \pm 0.2642$ & 4 \\
\hline 38. ANGLO AMERICAN & Mining & $0.2188 \pm 0.2661$ & 4 \\
\hline 39. 3I GROUP & Financial General & $0.2168 \pm 0.2380$ & 4 \\
\hline 40. HSBC HDG & Banks & $0.2139 \pm 0.2384$ & 3 \\
\hline 41. AVIVA & Insurance & $0.2106 \pm 0.2703$ & 6 \\
\hline 42. BARCLAYS & Banks & $0.2091 \pm 0.2893$ & 8 \\
\hline 43. BERKELEY GROUP & House, Leisure \& Personnel & $0.2084 \pm 0.2683$ & 6 \\
\hline 44. ROYAL BANK OF SCTL. & Banks & $0.2040 \pm 0.2117$ & 0 \\
\hline 45. BURBERRY GROUP & House, Leisure \& Personnel & $0.1990 \pm 0.2541$ & 6 \\
\hline 46. HAMMERSON & Real Estate & $0.1927 \pm 0.2591$ & 2 \\
\hline 47. LEGAL \& GENERAL & Insurance & $0.1855 \pm 0.2196$ & 1 \\
\hline 48. STANDARD CHARTERED & Banks & $0.1831 \pm 0.2241$ & 1 \\
\hline 49. BARRATT & House, Leisure \& Personnel & $0.1807 \pm 0.2708$ & 6 \\
\hline
\end{tabular}


Table 5 (Cont.) FTSE100 Corporate Ranking: Average Boundary Constructs adopted

\begin{tabular}{|c|c|c|c|}
\hline \multicolumn{4}{|c|}{ Reputation Management Boundary } \\
\hline 50. PEARSON & Media & $0.1779 \pm 0.2133$ & 2 \\
\hline 51. IHG & Travel \& Leisure & $0.1746 \pm 0.2359$ & 2 \\
\hline 52. BAE SYSTEMS & Aerospace \& Defence & $0.1681 \pm 0.1702$ & 1 \\
\hline 53. TRAVIS PERKINS & Support Services & $0.1640 \pm 0.2728$ & 7 \\
\hline 54. WHITBREAD & Travel \& Leisure & $0.1640 \pm 0.2061$ & 2 \\
\hline 55. MORRISON(WM) & Retailers & $0.1623 \pm 0.2133$ & 3 \\
\hline 56. MEDICLINIC INTERNL & Health Care Equip \& Services & $0.1615 \pm 0.2334$ & 1 \\
\hline 57. SABMILLER & Food \& Beverages & $0.1596 \pm 0.2068$ & 1 \\
\hline 58. SMITHS GROUP & Industrial general & $0.1522 \pm 0.1721$ & 0 \\
\hline 59. PROVIDENT FINANCIAL & Financial General & $0.1515 \pm 0.2135$ & 3 \\
\hline 60. TESCO & Retailers & $0.1494 \pm 0.1898$ & 1 \\
\hline 61. STANDARD LIFE & Financial General & $0.1463 \pm 0.1876$ & 1 \\
\hline 62. CAPITA & Support Services & $0.1463 \pm 0.1876$ & 1 \\
\hline 63. LAND SECURITIES & Real Estate & $0.1441 \pm 0.2215$ & 3 \\
\hline 64. LONDON STOCK EX. & Financial General & $0.1362 \pm 0.2006$ & 1 \\
\hline 65. LLOYDS & Banks & $0.1359 \pm 0.1660$ & 1 \\
\hline 66. SHIRE & Pharmaceuticals \& Biotech & $0.1354 \pm 0.1995$ & 0 \\
\hline 67. SMITH \& NEPHEW & Health Care Equip \& Services & $0.1327 \pm 0.1919$ & 1 \\
\hline 68. CENTRICA & Utilities & $0.1304 \pm 0.2586$ & 5 \\
\hline 69. GKN & Automobiles \& Parts & $0.1286 \pm 0.2174$ & 1 \\
\hline 70. PERSIMMON & House, Leisure \& Personnel & $0.1286 \pm 0.1982$ & 0 \\
\hline 71. ITV & Media & $0.1283 \pm 0.1751$ & 1 \\
\hline 72. MERLIN ENTERTAINMENTS & Travel \& Leisure & $0.1254 \pm 0.1975$ & 1 \\
\hline 73. INTERTEK GROUP & Support Services & $0.1239 \pm 0.2082$ & 2 \\
\hline 74. DIRECT LINE & Insurance & $0.1203 \pm 0.1888$ & 1 \\
\hline 75. OLD MUTUAL & Insurance & $0.1203 \pm 0.1827$ & 1 \\
\hline 76. INFORMA & Media & $0.1203 \pm 0.1494$ & 0 \\
\hline 77. COCA-COLA HBC & Food \& Beverages & $0.1187 \pm 0.1914$ & 1 \\
\hline 78. INTL.CONS.AIRL. & Travel \& Leisure & $0.1183 \pm 0.1671$ & 1 \\
\hline 79. TUI (LON) & Travel \& Leisure & $0.1107 \pm 0.1595$ & 0 \\
\hline 80. INTU PROPERTIES & Real Estate & $0.1026 \pm 0.1900$ & 1 \\
\hline 81. COMPASS GROUP & Travel \& Leisure & $0.0997 \pm 0.1626$ & 1 \\
\hline 82. PRUDENTIAL & Insurance & $0.0994 \pm 0.1379$ & 0 \\
\hline 83. NATIONAL GRID & Utilities & $0.0990 \pm 0.1980$ & 1 \\
\hline 84. DIXONS CARPHONE & Retailers & $0.0893 \pm 0.1605$ & 0 \\
\hline 85. EXPERIAN & Support Services & $0.0893 \pm 0.1430$ & 0 \\
\hline 86. SCHRODERS & Financial General & $0.0904 \pm 0.1551$ & 1 \\
\hline 87. ASHTEAD GROUP & Support Services & $0.0865 \pm 0.1628$ & 1 \\
\hline 88. SAGE GROUP & Technology & $0.0841 \pm 0.1319$ & 0 \\
\hline 89. ARM HOLDINGS & Technology & $0.0786 \pm 0.1218$ & 0 \\
\hline 90. BABCOCK INTERNL & Support Services & $0.0781 \pm 0.1871$ & 2 \\
\hline 91. ADMIRAL GROUP & Insurance & $0.0734 \pm 0.1493$ & 1 \\
\hline 92. RSA INSURANCE GROUP & Insurance & $0.0734 \pm 0.1196$ & 0 \\
\hline 93. EASYJET & Travel \& Leisure & $0.0666 \pm 0.1313$ & 0 \\
\hline 94. ST.JAMES'S PLACE & Insurance & $0.0666 \pm 0.1262$ & 0 \\
\hline 95. WORLDPAY GROUP & Support Services & $0.0657 \pm 0.0993$ & 0 \\
\hline 96. HARGREAVES LANSDOWN & Financial General & $0.0578 \pm 0.0988$ & 0 \\
\hline 97. DCC & Support Services & $0.0522 \pm 0.1092$ & 0 \\
\hline 98. WOLSELEY & Support Services & $0.0501 \pm 0.0948$ & 0 \\
\hline 99. PADDY POWER BETFAIR & Travel \& Leisure & $0.0500 \pm 0.0947$ & 0 \\
\hline 100.HIKMA PHARMA & Pharmaceuticals \& Biotech & $0.0313 \pm 0.0982$ & 0 \\
\hline
\end{tabular}


Figure 1: Theoretical Radar Graphs of Reporting Content According to Boundary Setting Categories within Sustainability Reporting

\begin{tabular}{|c|c|c|c|c|}
\hline Boundary Name & Reputation Management & Ownership and Control & Accountability & Stakeholder Engagement \\
\hline $\begin{array}{l}\text { Logical radar } \\
\text { graph example } \\
\text { for unilateral } \\
\text { (topic-by-topic) } \\
\text { application }\end{array}$ & 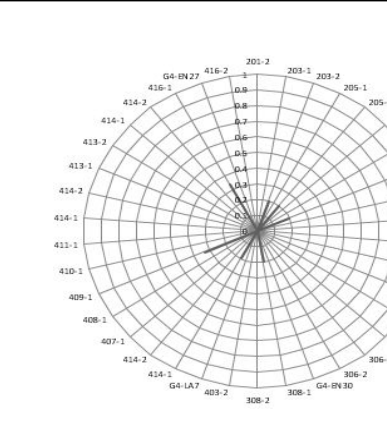 & -2 & 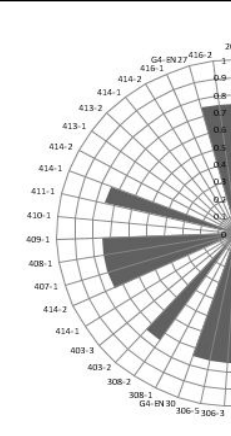 & 8 \\
\hline $\begin{array}{l}\text { Logical radar } \\
\text { graph example } \\
\text { for universal } \\
\text { application }\end{array}$ & (2) & 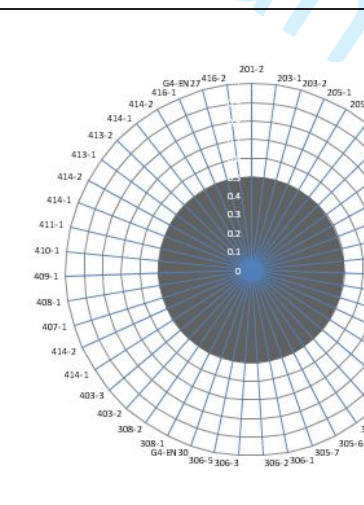 & (2) & 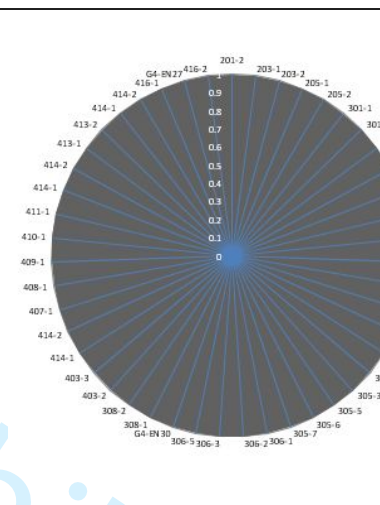 \\
\hline
\end{tabular}


Figure 2: A Conceptual Model of Boundary Setting in Sustainability Reporting
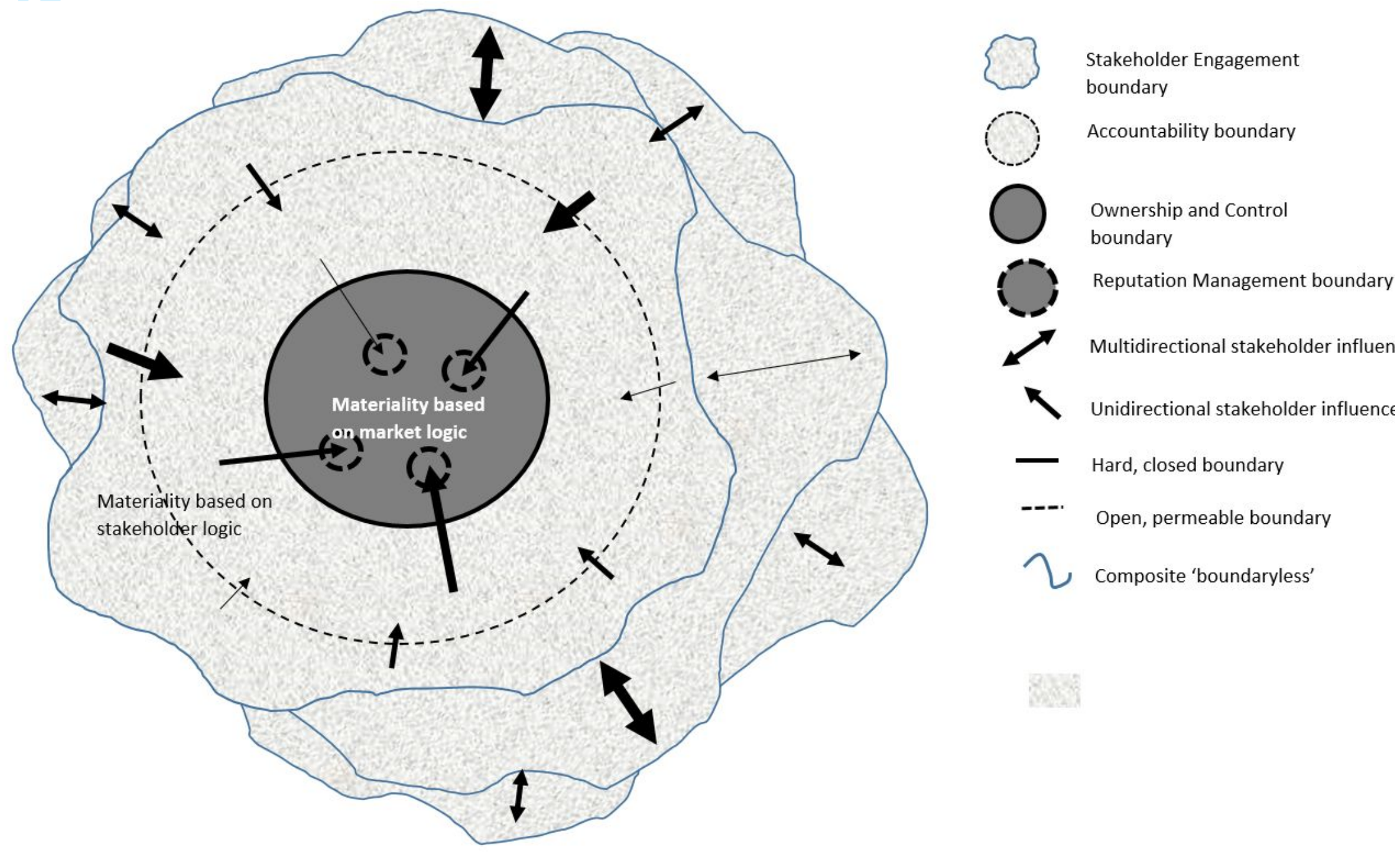
Figure 3: Average Boundary Setting for the FTSE100

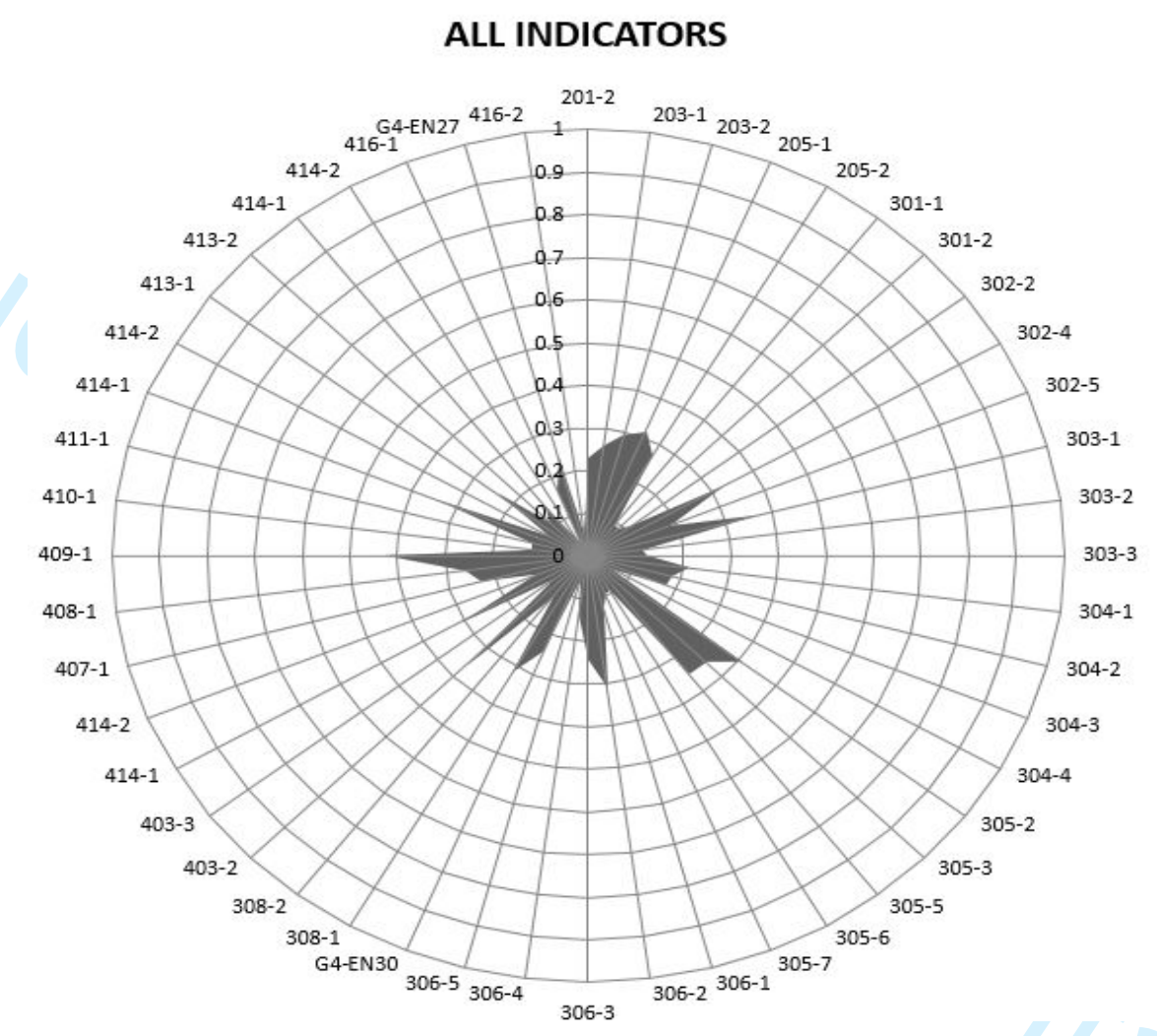

Boundary Scale 0-1

0-0.249 Reputation Management

0.25-0.499 Ownership and control

0.5-0.749 Accountability

0.75-1.00 Stakeholder Engagement 
Figure 4: Aspect Boundaries of 49 GRI Indicators for ten FTSE100 companies demonstrating the widest boundary setting

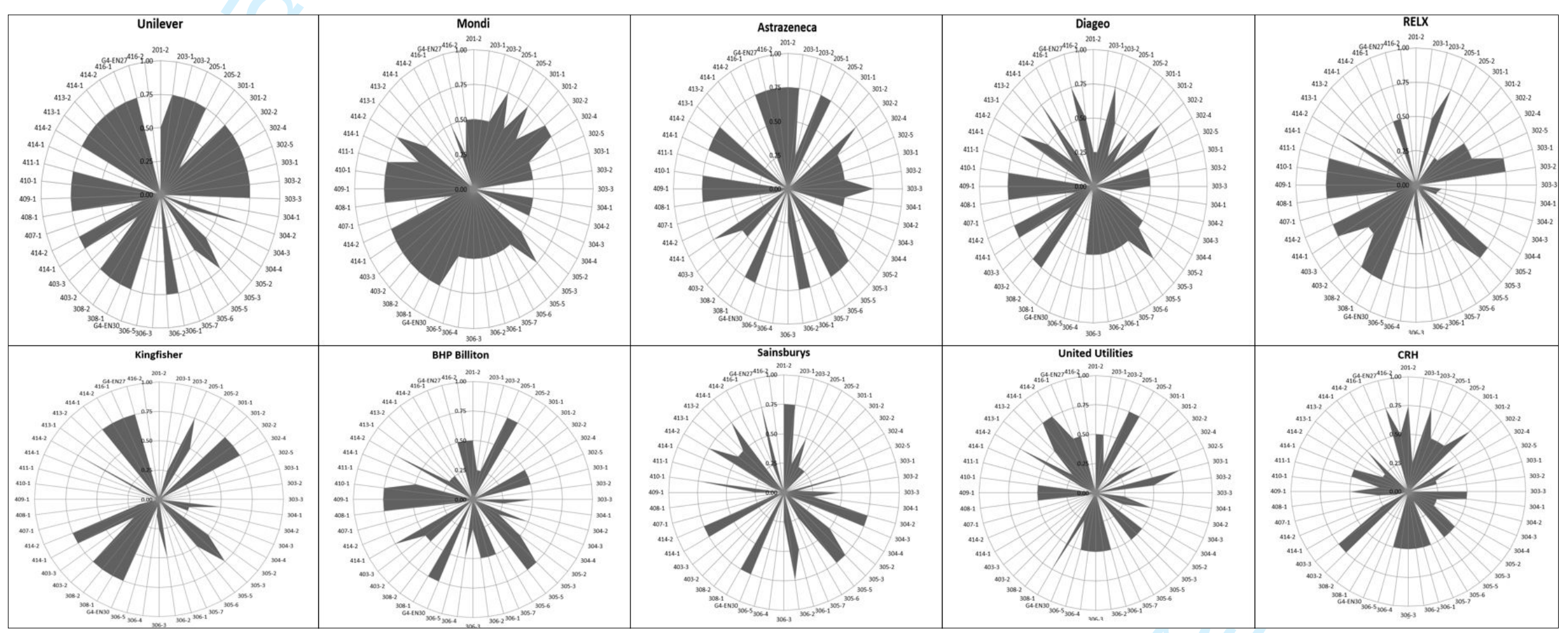


Appendix 1: GRI indicators used for Content Analysis

\begin{tabular}{|c|c|c|}
\hline G4 & $\begin{array}{c}\text { GRI } \\
\text { Standard }\end{array}$ & Summary Description \\
\hline \multicolumn{3}{|l|}{ Labour } \\
\hline LA6 & $403-2$ & Type of Injury, rates of injury, occupational diseases, lost days, absenteeism, work-related fatalities \\
\hline LA7 & $403-3$ & Workers with high incidence of risk of disease related to occupation \\
\hline LA14 & 414-1 & $\%$ new suppliers screened using labour practices criteria \\
\hline LA15 & $414-2$ & Significant (actual/potential) negative impacts for labour practices in the supply chain \& actions taken \\
\hline \multicolumn{3}{|l|}{ Society } \\
\hline SO1 & $413-1$ & $\begin{array}{l}\% \text { operations with implemented local community engagement, impact assessments \& development } \\
\text { programs }\end{array}$ \\
\hline $\mathrm{SO} 2$ & $413-2$ & Operations with significant (actual/potential) negative impacts on local communities \\
\hline SO9 & $414-1$ & $\%$ new suppliers screened using criteria for impacts on society \\
\hline SO10 & $414-2$ & Significant (Actual/potential) negative impacts on society in the supply chain \& actions taken \\
\hline \multicolumn{3}{|c|}{ Economic } \\
\hline EC2 & $201-2$ & Financial implications and other risks and opportunities due to climate change \\
\hline EC7 & $203-1$ & Development \& impact of infrastructure investments \& services supported \\
\hline EC8 & $203-2$ & Significant indirect economic impacts \& extent of impacts \\
\hline SO3 & $205-1$ & Business units analysed for risks related to corruption \\
\hline SO4 & $205-2$ & Communication and training on anti-corruption policies and procedures \\
\hline \multicolumn{3}{|c|}{ Human Rights } \\
\hline HR4 & $407-1$ & $\begin{array}{l}\text { Operations \& suppliers identified in which the right to exercise freedom of association \& collective } \\
\text { bargaining may be violated or at significant risk, support measures taken }\end{array}$ \\
\hline HR5 & $408-1$ & $\begin{array}{l}\text { Operations \& suppliers identified as having significant risk for incidents of child labour, measures taken } \\
\text { to contribute to effective abolition of child labour }\end{array}$ \\
\hline HR6 & $409-1$ & Operations with risks for incidents of forced or compulsory labour \\
\hline HR7 & $410-1$ & Security personnel trained on human rights \\
\hline HR8 & $411-1$ & Incidents of violations involving the rights of indigenous peoples \\
\hline HR10 & $414-1$ & $\%$ new suppliers screened using human rights criteria \\
\hline HR11 & $414-2$ & Significant (Actual/potential) negative human rights impacts in the supply chain \& actions taken \\
\hline HR12 & $414-2$ & Grievances about human rights \\
\hline \multicolumn{3}{|c|}{ Product Responsibility } \\
\hline PR1 & $416-1$ & Health and safety of products \\
\hline PR2 & $416-2$ & Non-compliance with regulations concerning health and safety of products \\
\hline EN27 & - & Extent of impact mitigation of environmental impacts of products and services \\
\hline
\end{tabular}




\section{Appendix 1: GRI indicators used for Content Analysis (continued)}

\begin{tabular}{|c|c|c|}
\hline G4 & $\begin{array}{l}\text { GRI } \\
\text { Standard }\end{array}$ & Summary Description \\
\hline \multicolumn{3}{|c|}{ Environment } \\
\hline EN1 & $301-1$ & Materials used by weight or volume \\
\hline EN2 & $301-2$ & Percentage of materials used that are recycled input materials \\
\hline EN4 & $302-2$ & Energy consumption outside of the organization \\
\hline EN6 & $302-4$ & Reduction of energy consumption \\
\hline EN7 & $302-5$ & Reduction in energy requirements of products and services \\
\hline EN8 & $303-1$ & Total water withdrawn by source \\
\hline EN9 & $303-2$ & Water sources significantly affected by withdrawal of water \\
\hline EN10 & $303-3$ & Water recycled and reused \\
\hline EN11 & $304-1$ & Sites in protected areas and areas of high biodiversity value \\
\hline EN12 & $304-2$ & Significant impacts on biodiversity in protected areas \& areas of high biodiversity value \\
\hline EN13 & $304-3$ & Habitats protected or restored \\
\hline EN14 & 304.4 & IUCN Red List Species in areas affected by operations \\
\hline EN16 & $305-2$ & Energy indirect GHG emissions (Scope 2) \\
\hline EN17 & $305-3$ & Other indirect GHG emissions (Scope 3) \\
\hline EN19 & $305-5$ & Reductions of GHG emissions \\
\hline EN20 & $305-6$ & Emissions of ozone-depleting substances \\
\hline EN21 & $305-7$ & NOx, SOx, and other significant air emissions \\
\hline EN22 & $306-1$ & Water discharge by quality and destination \\
\hline EN23 & $306-2$ & Waste by type and disposal method \\
\hline EN24 & $306-3$ & Significant spills \\
\hline EN25 & $306-4$ & Hazardous waste transported, imported, exported, treated and shipped internationally \\
\hline EN26 & $306-5$ & Water bodies and related habitats affected by organisation's water discharges and runoff \\
\hline EN30 & - & $\begin{array}{l}\text { Significant environmental impacts of transporting products, goods \& materials \& transporting } \\
\text { members of the workforce }\end{array}$ \\
\hline EN32 & $308-1$ & $\%$ new suppliers screened using environmental criteria \\
\hline EN33 & $308-2$ & Significant (Actual/potential) negative environmental impacts in the supply chain \& actions taken \\
\hline
\end{tabular}

